\title{
MILITES APOLLINIS. STUDENTI MEDICÍNY Z ČESKÝCH ZEMÍ NA BASILEJSKÉ UNIVERZITĚ V 16. A RANÉM 17. STOLETÍ
}

\author{
MARTIN HOLÝ - MARTA VACULÍNOVÁ
}

\section{MILITES APOLLINIS. STUDENTS OF MEDICINE FROM THE CZECH LANDS AT THE UNIVERSITY OF BASEL IN THE SIXTEENTH AND EARLY SEVENTEENTH CENTURY}

This contribution is a preliminary study for a monograph on students from the Czech Lands in Basel, focusing on those who studied medicine. It maps their geographic and social origin, their adherence to religious denominations, the curricula they followed, as well as their careers after a completion of their studies. Separately, attention is paid to their literary activities, which was mostly academic, but also related less formal literary creations.

Keywords: history of education - history of medicine - University of Basel - Neo-Latin literature - humanist correspondence - students from the Czech Lands abroad

DOI: $10.14712 / 23365730.2021 .17$

\section{I. Úvodem}

Univerzita v Basileji byla založena na základě buly papeže Pia II. z listopadu 1459 . Ke slavnostnímu otevření došlo však teprve na jaře 1460. Spojena byla do značné míry s biskupstvím, respektive katedrální kapitulou. Prvním rektorem byl její probošt, alsaský šlechtic Georg von Andlau († 1466). Již od počátku byla koncipována jako plnohodnotné studium generale se všemi čtyřmi obvyklými fakultami, tedy artistickou, právnickou, lékařskou a teologickou. Podmínkou studia na vyšších fakultách bylo dlouhou dobu absolvování první z nich. ${ }^{1}$

Ačkoli první obyvatele českého státu najdeme v Basileji již v pozdním středověku, čehož si dosavadní domácí bádání nepovšimlo, jejich počet mezi studenty basilejské univerzity výrazněji narůstá teprve v raném novověku, a to zejména od 30.-50. let 16. století. Přestože nemalou část imatrikulovaných z Čech a Moravy až do 30. let 17. století tvořili šlechtici,

1 K dějinám basilejské univerzity i některých jejích fakult ve sledovaném období srov. alespoň Rudolf THOMMEN, Geschichte der Universität Basel 1532-1632, Basel 1889; Albrecht BuRCKHARDT, Geschichte der Medizinischen Fakultät zu Basel 1460-1900, Basel 1917; Edgar Bonjour, Zur Gründungsgeschichte der Universität Basel, Basler Zeitschrift für Geschichte und Altertumskunde 54, 1955, s. 27-50; TÝŽ, Die Universität Basel, von den Anfängen bis zur Gegenwart, Basel 1960; Andreas Staehelin (Hg.), Professoren der Universität Basel aus fünf Jahrhunderten. Bildnisse und Würdigungen, Basel 1960; Guido KIsch, Die Anfänge der Juristischen Fakultät der Universität Basel 1459-1529, Basel 1962. 
pro něž samotné univerzitní studium plnilo spíše subsidiární úlohu v procesu výchovy a vzdělávání, najdeme přeci jen mezi imatrikulovanými také desítky jednotlivců pocházejících z královských či jiných měst, případně poddanských lokalit. Zejména pokud netvořili doprovod nobility (vychovatelé, famulové), patřily mezi ně mnohé osoby, které se v Basileji intenzivně věnovaly studiu a často je zde rovněž formálně zakončily. ${ }^{2}$

Vedle početných jednotlivců studujících na artistické fakultě a naopak relativně omezeného okruhu obyvatel českého státu věnujících se teologickým studiím a později působícím především v církevní správě Jednoty bratrské (vedle ní ovšem také v jiných konfesních prostředích) se jednalo především o studenty práv a medicíny. Právě poslední jmenovaná skupina byla mezi rodáky z Čech a Moravy zastoupena dosti výrazně. Zároveň v ní najdeme největší procento těch, kteří studium formálně zakončili ziskem cenného doktorátu medicíny, který byl v intelektuálním světě vnímán do jisté míry jako ekvivalent nobilitace $^{3}$ a jenž jim většinou výrazně napomohl v jejich další kariéře. ${ }^{4}$

Právě na tyto osobnosti se zaměří předkládaná studie. Za předpokladu, že započítáme nikoli pouze ty $\mathrm{z}$ nich, kteří v Basileji formálně ukončili studium medicíny ziskem doktorátu (drtivá většina, viz níže), ale také jedince, u nichž k tomu nedošlo, tak se celkem jedná o 30 jednotlivců. V kontextu akademické peregrinace obyvatel českého státu ${ }^{5}$ za vyššími akademickými tituly (doktoráty práv, medicíny a teologie), kterých v jagellonské a předbělohorské době nebylo možné až na výjimky v Čechách dosáhnout, se tak Basilej ukazuje jako zcela jedinečné místo mající podstatný význam pro formování několika generací této specifické profese, které ovlivnily lékařství nejen v českých zemích, ${ }^{6}$ ale také jinde, kde tito lékaři rozvíjeli další kariéru (viz dále, oddíl III).

$\mathrm{K}$ výzkumu dané problematiky jsou použitelné jak prameny úřední povahy (matriky, úřední korespondence apod.), tak také egodokumenty (např. deníky různého druhu, včetně

2 František Šmahel, Alma mater Pragensis. Studie k počátkům Univerzity Karlovy, Praha 2016, s. 457 (zde uvedeni jako první studenti až v období po 1533); Hans Georg WACKERNAGEL (Hg.), Die Matrikel der Universität Basel, I-III, Basel 1951, 1956, 1962 (dále jen Matrikel Basel); Karel SiтA, Studenti z českých zemí na basilejské univerzitě v době reformace, Theologická prŕíloha Křest’anské revue 21, 1954, s. 14-19. Ke šlechtickým studentům a jejich doprovodu srov. alespoň Martin HolÝ, Zrození renesančního kavalíra. Výchova a vzdèlávání šlechty z českých zemi na prahu novověku (1500-1620), Praha 2010, s. 364n. a passim (dle rejstříku); TÝž, Ve službách šlechty. Vychovatelé nobility z českých zemí (1500-1620), Praha 2011, s. 68-76 a passim (dle rejstř́íku).

3 Marian Füssel, Gelehrtenkultur in Basel, (zde i starší literatura), online: < https://unigeschichte.unibas.ch /fileadmin/user_upload/pdf/Fuessel_Gelehrtenkultur.pdf> (13. 6. 2021).

4 Tyto i další údaje vycházejí z dat shromážděných v rámci řešení grantového projektu uvedeného za textem.

5 Srov. i s dalšími odkazy Jiří PEŠEK - David ŠAMAN, Studenti z Čech na zahraničních universitách v predbělohorském čtvrtstoletí, Ústecký sborník historický 1983, s. 173-218; Kateřina ScHWABIKovÁ, Česká šlechta a univerzity némecké jazykové oblasti v raném novověku (Čeští páni a rytíri, imatrikulovaní v letech 1550-1620 na univerzitách nynéjšiho Německa, Rakouska a Švýcarska), AUC-HUCP 46/1-2, 2006, s. 25-131; Martin HolÝ, Vzdělanostni migrace v česko-německém prostoru v 16. a raném 17. století, in: Stanislav Brouček (ed.), Navzdory hranici. Migrační procesy na česko-německém pomezí / Trotz der Grenze. Migrationsprozesse im tschechisch-deutschen Grenzgebiet, Plzeň 2013, s. 18-31.

6 K dějinám medicíny v českých zemích srov. i s odkazy na další literaturu především Petr SvoBodNÝ - Ludmila HLAVÁČKOvÁ, Dějiny lékařství v českých zemích, Praha 2004. K poznání lékařské profese v Čechách a na Moravě ve zkoumané době je v mnoha ohledech cenná také práce Ludmily HLAvÁčKové a kol., Biografický slovník pražské lékařské fakulty 1348-1939, I-II, Praha 1988-1993. 
důležitých deníků cestovních, ${ }^{7}$ šlechtické i měštanské štambuchy, ${ }^{8}$ korespondence) či prameny literární (školské disputace, lékařské disertace a další literární texty, ${ }^{9}$ další př́ležitostná humanistická literatura apod.). ${ }^{10}$ Při studiu řady aspektů zkoumané problematiky je využitelná též řada děl, která vznikla ještě v průběhu raného novověku. Jedná se zejména o biografické či bio-bibliografické práce. ${ }^{11}$ Zcela klíčovou úlohu hrají pak rovněž některé lexikony 19.-21. století, stejně jako databáze prudce se rozvíjející zejména v posledních deseti až patnácti letech. ${ }^{12}$ (obr. 1 )

\section{Geografická, jazyková/národnostní, konfesní a sociální skladba zkoumaného vzorku}

Co se týče geografické skladby zkoumaných osobností, narodila se jich těsná nadpoloviční většina v Čechách (šestnáct osob), zbytek pak bud' na Moravě, anebo v Opavském knížectví, které po většinu sledované doby netvořilo ještě jasnou součást Slezska, byt' k němu postupně čím dál více inklinovalo (potvrzeno formálně Matyášem I. i v souvislosti s udělením léna Karlovi z Lichtenštejna 1613). ${ }^{13}$ Proto jsme osoby narozené v Opavě do studie započítali.

Z hlediska typů lokalit, z nichž zkoumané osoby pocházely, jsou mezi nimi nejčastěji zastoupena královská města, nejpočetněji pak Praha, a to celkem v sedmi př́ípadech (často

7 K deníkům v českém (zvláště šlechtickém) prostředí 16. a 1. poloviny 17. století srov. Petr MAŤA, Nejstarši české a moravské deníky (Kultura každodenniho života v raném novověku a některé nové perspektivni prameny), Folia historica Bohemica 18, 1997, s. 99-120; TÝž, Tagebücher, in: Josef Pauser - Martin Scheutz - Thomas Winkelbauer (Hgg.), Quellenkunde der Habsburgermonarchie (16.-18. Jahrhundert). Ein exemplarisches Handbuch, Wien - München 2004, s. 767-780. Ze zahraniční literatury srov. alespoň: Gustav René HockE, Das europäische Tagebuch, Wiesbaden 1963; Ralph Rainer Wuthenow, Europäische Tagebücher. EigenartFormen - Entwicklung, Darmstadt 1990.

8 Marie RyantovÁ, Památniky aneb štambuchy, to jest alba amicorum. Kulturně historický fenomén raného novovéku, České Budějovice 2007, zde na s. 441-479 další literatura ke štambuchům.

9 Disputace př́mo související se studiem v Basileji zachycuje Fritz Husner, Verzeichnis der Basler Medizinischen Universitätsschriften von 1575-1829, Basel 1942.

10 Bohemikální literaturu tohoto typu zachycuje především Antonín TruHLÁr̆ - Karel HRdina - Josef HeJNIC - Jan MARTíneK, Rukovět humanistického básnictví v Čechách a na Moravě, I-VI, (dále RHB), Praha 1966-2011.

11 Viz alespoň Melchior AdAm, Vitae Germanorum medicorum qui seculo superiori, et quod excurrit, claruerunt congestae, Heidelberg: Geyder 1620; Paul FreHER, Theatrum virorum eruditione clarorum, Norimberk: Hofmann 1688; Johannes Henricus CunRAdus, Silesia togata, sive Silesiorum doctrina et virtutibus clarissimorum elogia, Lehnice: Rorlach 1706 (BU Wrocław, sign. 440.824); Johann Heinrich ZedLeR, Grosses vollständiges Universal-Lexicon aller Wissenschaften und Künste, I-LXIV, Halle - Leipzig 1732-1750; Christian Gottlieb JöCHER, Allgemeines Gelehrten-Lexicon, I-IV, Leipzig 1750-1751 (+ Nachträge).

12 Z první skupiny jde vedle již výše zmíněné RHB např. o Gottlieb Friedrich Oтто, Lexikon der seit dem funfzehenden Jahrhunderte verstorbenen und jeztlebenden Oberlausizischen Schriftsteller und Künstler, Görlitz 1800; Jonas Graetzer, Lebensbilder hervorragender Ärzte aus den letzten vier Jahrhunderten, Breslau 1889; Michael SAchs, Historisches Ärztelexikon für Schlesien. Biographisch-Bibliographisches Lexikon schlesischer Ärzte und Wundärzte (Chirurgen), I, Wunstorf 1997; Heribert StuRm (Hg.), Biographisches Lexikon der Böhmischen Länder, I-IV, München 1979-2018; Biografický slovník českých zemi I-XXIII, Praha 2004-2020; Lucie Storchová (ed.), Companion to Central and East European Humanism II/1, Berlin 2020. Z databází jsou využitelné např. <www.vd16.de>; <www.vd17.de>; <www.knihopis.cz >; <knihoveda.cz>; <www .provenio.net $>$; $<$ www.raa.phil.uni-erlangen.de $>$; $<$ www.deutsche-biographie.de $>$; $<$ http://www.rag-online .org >; <www.e-rara.ch>; <www.e-manuscripta.ch>, <www.e-codices.unifr.ch/de> (10. 6. 2021).

13 Petr Vorel, Velké dějiny zemi Koruny české, VII, 1526-1618, Praha 2005, s. 52; Zdeněk JiRÁseK a kol., Slezsko v dějinách Českého státu, II, 1490-1763, Praha 2012, zejména s. 59-78. 
ovšem není možné určit původ z konkrétního z pražských měst), z českých zeměpanských měst dále Jáchymov, Kadaň, Kutná Hora, Litoměřice či Louny, z moravských pak Brno a Znojmo. Početně zastoupená Opava (šest jednotlivců) byla zmíněna již výše. Řada budoucích basilejských studentů medicíny se však narodila také v poddanských městech či drobných lokalitách, a to jak v Českém království, tak také v Markrabství moravském (podrobněji srov. graf na konci studie).

Určit jazykovou skladbu sledovaného vzorku není jednoduché, u řady jednotlivců není jasné, zda šlo o Čechy, či Němce. Obě tyto skupiny najdeme mezi nimi početně zastoupené. $\mathrm{V}$ některých případech je možné předpokládat $\mathrm{i}$ bilingvní jedince. Podobně obtížně lze na základě dochovaných pramenů zjistit konfesijní strukturu zkoumaných osob. U značné části z nich chybí jasné zprávy o př́slušnosti k určitému vyznání. Je také zapotřebí počítat s možnostmi konverzí v rámci jednotlivých protestantských denominací, př́padně po Bílé hoře se změnou vyznání ke katolicismu.

U několika osobností je zřejmá či vysoce pravděpodobná přináležitost $\mathrm{k}$ Jednotě bratrské. ${ }^{14}$ Zejména $\mathrm{v}$ př́ípadě rodáků $\mathrm{z}$ částečně či majoritně německojazyčných lokalit lze očekávat rovněž luterány. Vedle nich pak zcela jistě najdeme i osoby inklinující k domácímu utrakvismu, př́ípadně ke kalvínství. V každém případě lze u všech sledovaných osobností předpokládat $\mathrm{v}$ době jejich studií v Basileji nekatolické vyznání. Katolíkủm, kteří v pozdním 15. až raném 17. století tvořili v českých zemích výraznou minoritu, se v dané době nabízela lékařská studia jinde, at' již na některých univerzitách v Říši, včetně rakouských zemí, ve Francii a hlavně v Itálii. ${ }^{15}$

Obtížné je rovněž posoudit sociální strukturu zkoumaných osobností. Ve většině př́ípadů nedisponujeme informacemi o jejich rodičích, případně jejich sociální př́slušnosti, majetkovém zázemí či profesi. Zejména se to týká rodáků z nekrálovských měst v Čechách a na Moravě. Pokud jde o osoby narozené v zeměpanských lokalitách, i tam jsou ovšem podobné informace spíše méně četné. $V$ některých př́ípadech však víme, že zkoumané osobnosti pocházely z již významných měštanských rodin, včetně rodin radních, měly nobilitované otce, ${ }^{16}$ př́padně je zřejmá přináležitost $\mathrm{k}$ movité městské společnosti, $\mathrm{i}$ bez erbu. ${ }^{17}$

Několik jedinců pak ve vzdělávání následovalo kariéru otce či jiného př́ibuzného. Synem pražského lékaře a po nějaký čas také doktora ve službách Ferdinanda Tyrolského Jana Willebrocha byl Michael Willebroch, absolvent medicíny basilejské univerzity v roce 1586, léčitelstvím se měl zabývat také otec Simeona Partlicia ze Špicberku (1621 dr. med. v Basileji).$^{18}$ Potomkem proslulého astronoma Johanna Keplera (1571-1630) a Barbory

14 Uvedené platí např́íklad pro Matyáše Borbonia z Borbenheimu, Jana Škrétu Šotnovského ze Závořic či Matyáše Timina.

15 Srov. výše zmiňovanou studii J. Peška a D. Šamana, stejně jako tabulky v práci F. ŠMAHeLA, Alma mater Pragensis, s. 457n.

16 Týká se to např́klad Lucase Gillera z Lilienfeldu, Ondřeje Habrvešla z Habernfeldu (syn 1594 nobilitovaného staroměstského měšt’ana a sekretáře Rudolfa II. Albrechta Habrvešla), Valeria II. Polana (syn Heinricha I. Polana), Jana Stodolia z Požova, Jana Škréty ze Závořic (syn Konráda Škréty a Kateřiny z Morchendorfu, bratr proslulého barokního malí̌re Karla Škréty), Štěpána, syna novoměstského měšt’ana Tobiáše Štefka, popraveného 1621 za účast na stavovském povstání na Starém Městě pražském, či Daniela Štyrkolského z Volovice (syn Eliáše Štyrkolského, mistra pražské univerzity a litoměřického měšt'ana). K erbovníkům viz zejména Vladimír KLECANDA, Tři kapitoly o českomoravských erbovnícich, Praha 1931.

17 Uvedené platí např́íklad pro Jana I. a Jana II. Richtery pocházející z Opavy.

18 K Michaelovi Willebrochovi viz alespoň Matrikel Basel, II, s. 340; Gustav Gellner, Životopis lékaře Borbonia a výklad jeho deníkủ, Praha 1938, s. 228; F. Husner, Verzeichnis, s. 31; Elias von SteinMeYer (Hg.), 
Müllerové byl v Praze narozený Ludwig Kepler (1607-1663), studující medicínu v Basileji ve 30 . letech 17 . století. ${ }^{19}$

U některých jednotlivců z poddanských rodin jsme přímo informováni o původu z chudých poměrů, např́ílad u Matyáše Borbonia z Borbenheimu (1566-1629), známého lékaře zanechavšího deník dotýkající se rovněž jeho basilejského pobytu. ${ }^{20}$ Teprve vzdělání, jehož se jim dostalo, jim umožnilo sociální a majetkový vzestup, v řadě př́padů také nobilitaci. Té pak dosáhla také řada osobností pocházejících z královských měst. V kontextu sledovaného okruhu osob je pak výjimečný př́pad opavského rodáka Matyáše Timina z Ottenfeldu († po 1636), který dosáhl především díky kontaktům s Karlem st. ze Žerotína přijetí do rytî́rského stavu na Moravě (1606). ${ }^{21}$

\section{Vzdělanostní profil a následné kariéry}

Vzdělanostní profil basilejských studentů medicíny z českých zemí je s ohledem na torzovitost dochování evidenčních pramenů (zejména matrik jednotlivých škol, př́ípadně jejich součástí) poznatelný pouze omezeně. Týká se to zejména jejich preuniverzitních studií. O nich máme letmé informace pouze u malého množství z nich. Doložena jsou tak zejména partikulární studia na městských školách v několika českých královských či vrchnostenských městech (pražské souměstí, Chrudim, Klatovy, Kolín, Kutná Hora, Rakovník, Slaný, Žatec ad.), př́ípadně na Opavsku (městská škola v Opavě) a ve vedlejších zemích České koruny (Zhořelec), u Ludwiga Keplera a Jana Škréty pak také v zahraničí (u prvního Linec, Řezno, Vídeň, Sulzbach, u druhého gymnázium v Brémách). ${ }^{22}$

I pokud jsou doložena studia sledovaných osob na některé z uvedených škol, resp. na více $\mathrm{z}$ nich - běžně jich totiž, jak uvidíme dále na dvou konkrétních př́íkladech, postupně vystř́ídali více - často nevíme, jak dlouho na nich získávali vzdělání, jakými třídami prošli, jak rychle je absolvovali apod. I v takových př́padech jsou tedy naše informace o jejich

Die Matrikel der Universität Altdorf (1575-1809), I-II, Würzburg 1912, zde I, s. 13; II, s. 623; Heinrich Kunstmann, Die Nürnberger Universität Altdorf und Böhmen. Beiträge zur Erforschung der Ostbeziehungen deutscher Universitäten, Köln - Graz 1963, s. 225.

19 K pobytu Johanna Keplera v Praze i k jeho rodině viz alespoň Josef SMOLík, Mathematikové v Čechách od založeni university Pražské až do počátku tohoto století, I, Od r. 1348-1622, Praha 1865, s. 108nn.; Zdeněk HoRský, Kepler v Praze, Praha 1980; TÝž, Kepler and the Prague of Rudolph II., in: Jiří Janta - Jiří Niederle (edd.), Physics and Prague, Praha 2005, s. 55-68; Antonín ŠveJdA, Kepler a Praha, Praha 2004. K L. Keplerovi srov. alespoň August Hirsch, Biographisches Lexikon der hervorragenden Aerzte aller Zeiten und Völker, III, Wien 1886; s. 454n.; Ottův slovník naučný, XIV, Praha 1899, s. 171n.; Matrikel Basel, III, s. 326; F. HuSNER, s. 68 .

20 Max Dvořák (ed.), Dva deniky Matyáše Borbonia z Borbenheimu, Praha 1896; Gustav Gellner, Životopis lékaře Borbonia, Praha 1938. K Borboniovi viz také RHB I, s. 218nn.; Michal Svatoš, Cesta za vzděláním doktora medicíny Matyáše Borbonia, AUC-HUCP 35/1-2, 1995, s. 29-40; BSČZ VI, s. 53; M. HoLÝ, Ve službách šlechty, zejména s. 58-80, 139n.; L. STorchová (ed.), Companion to Central and East European Humanism II/1, s. 188-195.

21 K němu viz alespoň M. HoLÝ, Ve službách šlechty, s. 311nn.

22 K systému vzdělávání v zemích České koruny srov. v komparativní perspektivě Martin HolÝ, Vzdělanostní mecenát v zemích České koruny (1500-1700), Praha 2016, s. 61nn. 130nn., 156nn., 166nn.; TÝž, Ähnlichkeit oder Differenz? Bildungssysteme in den Ländern der Böhmischen Krone im 16. und 17. Jahrhundert, in: Christine Freytag - Markus Friedrich - Sascha Salatowsky, Frühneuzeitliche Bildungssysteme im interkonfessionellen Vergleich. Inhalte - Infrastrukturen - Praktiken, Stuttgart 2018, s. 39-51. 
preuniverzitním vzdělávání bohužel pouze rámcové. Penzum poznatků, které mohli nabýt a jež je u části z nich alespoň teoreticky podrobněji poznatelné díky několika dochovaným školním řádům či literárním pramenům vzešlým z teoretické či praktické části výuky na jednotlivých z výše uvedených latinských škol, bylo u většiny z nich podobné. Sledovaní jednotlivci se na nich naučili ve větší či menši míře slovem a písmem latinský jazyk a dále zvládli základy sedmera svobodných umění. To jim pro další studia na soudobých vysokých školách (viz dále) dostačovalo.

I přes výše řečené si v ojedinělých případech můžeme učinit celistvější představu. Tak například jednu z výjimek z námi zkoumaných jednotlivců představuje již zmiňovaná osobnost Matyáše Borbonia z Borbenheimu. Narozen 1566 chodil po přesně neurčenou dobu do školy v rodišti (Kolinec u Klatov), asi od 1576 pak do městské školy v Sušici, dále v Klatovech (1577-1581), u sv. Štěpána v Praze, pak tamtéž u sv. Michala (1582), následně v Rakovníce (1583-1584), Kolíně (1584-1585), Chrudimi (1585-1586) a konečně ve Velkém Meziř́íći $(1586-1590) .{ }^{23}$

Na rozdíl od gymnaziálních studií víme více o vzdělávání se sledovaného okruhu osob na soudobých akademiích či univerzitách, a to jak předtím, než pobývali v Basileji, tak někdy i poté. Úplné informace máme však k dispozici zrŕ́dka. Často tak např́ílad neznáme místo zisku nižších akademických titulů u řady z doctores medicinae basilejské univerzity. Byt' studovat na vyšších fakultách v Basileji nebylo dlouho možné bez návštěvy nižších fakult, nelze vyloučit, že někteří držitelé doktorátu ze Švýcarska předchozí studia formálně nezakončili. Matriky evropských univerzit jsou však přeci jen dochovány torzovitě.

U některých osobností však podobnými informacemi disponujeme. Doložena jsou tak opakovaně např́klad bakalářským a/či magisterským titulem zakončená studia na pražské utrakvistické univerzitě, ${ }^{24} \mathrm{v}$ Heidelberku, ${ }^{25}$ Tübingen ${ }^{26}$ či Altdorfu. ${ }^{27}$ Studia předcházející pobytu v Basileji jsou však bez zisku akademického titulu doložena na řadě dalších akademií či univerzit, a to konkrétně v Boloni, Erfurtu, Frankfurtu nad Odrou, Heidelberku, Helmstedtu, Lipsku, Marburku, Padově, Sieně, Štrasburku či Vitemberku. V př́padě některých jednotlivců, kteří do zahraničí doprovázeli jako vychovatelé šlechtu, není ovšem zcela jasné, do jaké míry na daných školách skutečně studovali. Č́ást z nich k tomu však jednoznačně př́ležitost měla. ${ }^{28}$

23 Viz pozn. 20.

24 K absolventům pražského vysokého učení tak prokazatelně patřili Jan Emberiza (b. a. 1603), Václav Laurentii (1609 b. a., 1614 m. a.), Simeon Partlicius (1612 b. a., 1614 m. a.) či Daniel Stolcius (1618 b. a., 1619 m. a.). Ke všem srov. Karel BerÁNEK, Bakalárí a mistři Filozofické fakulty Univerzity Karlovy v Praze v létech 1586-1620, Praha 1989, passim (dle rejstř́íku).

25 Matyáš Erbinaeus (1607 m. a.), viz Gustav ToEPKe (Hg.), Die Matrikel der Universität Heidelberg, II, 1554 bis 1662, Heidelberg 1887, s. 231, 473.

26 Ludwig Kepler (1627 b. a., 1629 m. a.). Srov. Heinrich Hermelink (Hg.), Die Matrikeln der Universität Tübingen 1477-1600, II, Stuttgart 1906, s. 167.

27 Zde se stal mistrem svobodných umění 1583 Michael Willebroch z Prahy. Elias von SteInMEYER (Hg.), Die Matrikel der Universität Altdorf (1575-1809), Würzburg 1912, I, s. 13; II, s. 623.

28 Jako šlechtičtí vychovatelé se takto do zahraničí vydali např. Matyáš Borbonius, Jiří Fábuš, Simeon Partlicius či Valerius Polanus. Podrobněji k tomu Martin HolÝ, Die Privaterzieher des böhmischen und mährischen Adels und ihre Bildungsgänge am Beginn der Neuzeit, in: Juliane Jacobi - Jean Luc Le Cam - Hans-Ulrich Musolf (Hgg.), Vormoderne Bildungsgänge. Selbst- und Fremdbeschreibungen in der Frühen Neuzeit, Köln 2010, s. $169-187$. 
Některé sledované osobnosti studovaly na lékařských fakultách již před příchodem do Basileje. Jeden takový doklad je pro Vitenberk (Jan Plachetius), ${ }^{29}$ hned čtyři pak pro Helmstedt. Všichni jeho bývalí studenti zakončili svá lékařská studia ziskem doktorátu až ve Švýcarsku, v některých př́padech poměrně brzy po příchodu na basilejskou univerzitu. ${ }^{30}$ To je ovšem prípad i některých dalších osob zapsaných v matrikách výše uvedených univerzit bez dokladu, zda by tam ovšem studovaly právě lékařství. Naopak mimořádně časově vzdálená byla studia medicíny ve Štrasburku (1613) a Basileji (1627) u Georga Bienera z České Lípy. Mezi zápisem do univerzitní basilejské matriky a ziskem doktorátu je ovšem u něho pouze měsíc. Evidentně tedy musel přijít již dostatečně připraven $\mathrm{k}$ doktorským zkouškám. ${ }^{31}$ Zpravidla byla však mezi zápisem do basilejské matriky a ziskem doktorátu lékařství řada měsíců až několik let. Někdy mohl být mezi počátkem a formálním ukončením studia medicíny uskutečněn ještě pobyt na jiné univerzitě, jako tomu bylo např́klad u Johanna I. Richtera z Opavy, který se v Basileji imatrikuloval roku 1594, 1596-1597 absolvoval pobyty v Padově, Boloni a Sieně, načež se vrátil do Švýcarska, aby se zde 6. záŕí 1597 stal doktorem medicíny. ${ }^{32}$

Nejvyšší gradus medicinae však někteří ze sledovaných získali teprve při dalších studiích jinde. Například již zmíněný Ludwig Kepler studoval lékařství 1630/1631 v Basileji, následně od léta 1631 ve Štrasburku. Doktorát získal však teprve v Padově 1638. Mezitím působil mimo jiné také jako šlechtický vychovatel. ${ }^{33} \mathrm{~V}$ některých př́padech pak nevíme, kde byl později užívaný titul ve skutečnosti získán. ${ }^{34}$ Kromě některých průvodců šlechty či pobělohorských exulantů, kteří se do univerzitních matrik zapisovali běžně i v pokročilém věku, najdeme další místa studií následujících po Basileji, zejména pak po zisku doktorátu, jen výjimečně.

Co se týče následných kariér, našla většina doktorů medicíny basilejské univerzity uplatnění v tomto oboru. Jen $\mathrm{v}$ některých případech známe bližší časové údaje. Nezdá se ale, že by bylo obtížné najít pro ně obživu. Většina z nich se uplatnila jako lékaři v městském prostředí, a to nejen v českých zemích či ve vedlejších zemích České koruny, ale také v zahraničí. Působit tam přitom mohli př́mo v roli městských lékařư, anebo provozovali praxi soukromou. Kombinaci obojího najdeme u nich rovněž běžně, ${ }^{35}$ stejně jako v prrípadě

29 Carl Eduard Foerstemann et al. (edd.), Album academiae Vitebergensis. Ältere Reihe, I-III (1502-1602), Lipsiae - Hallis 1841-1894, díl II, s. 440.

30 Zde takto studovali Lucas Giller z Lilienfeldu, Ondřej Habrvešl, Caspar Cholius či Jan Mencelius. Srov. Paul Zimmermann (ed.), Album academiae Helmstadiensis, I, Hannover 1926, s. 155, 167n., 181, 184, 187.

31 Georg ErLen, Die Jüngere Matrikel der Universität Leipzig 1559-1809, I, Leipzig 1909, s. 33; Matrikel Basel III, s. 296.

32 Matrikel Basel II, s. 417; III, s. 296

33 Viz pozn. 19.

34 Např́klad Daniel Stolcius ze Stotzenberku, rodák z Kutné Hory, absolvent bakalářského i magisterského studia v Praze, studoval ve 20. letech lékařství v Lipsku, Marburku, Basileji či Frankfurtu. Kde dosáhl gradu uživaného nejpozději od 1630, není jasné. Podobně tomu bylo u Jana Emberizy studujícího lékařství od 1607 v Basileji, dále v Montpellier a Padově (titul užíval od 1612). Ke Stolciovi srov. vedle literatury citované v pozn. 99 alespoň RHB V, s. 198nn., k Emberizovi RHB II, s. 102.

35 Jednoznačně nejvíce informací o léčených pacientech i zastávaných pozicích máme $\mathrm{k}$ dispozici díky jeho deníkům zachycujícím také období po návratu do českých zemí ze Švýcarska u již opakovaně zmiňovaného Matyáše Borbonia z Borbenheimu. Srov. pozn. 20. 
těch, kteří se uplatnili ve službách české či moravské šlechty, př́ípadně některého z říšských knížat či v jednom prŕípadě švédského krále. ${ }^{36}$

Další možnost představovalo zaujetí pozice zemského lékaře či profesora některé vy̌̌ší latinské školy, akademie či univerzity. Tak např. brněnský rodák Jakob Behrnauer († 1630), který po studí́ch v Lipsku a Basileji získal ve druhém z měst 8 . července 1602 doktorát z medicíny, se následně stal profesorem lékařství na Schönaichianu v Bytomi nad Odrou, jehož byl 1616-1617 také rektorem. Po roce 1620 však odešel do Budyšína, kde byl ustanoven hornolužickým zemským lékařem. ${ }^{37}$ Zemské lékaře najdeme však také v Čechách, na Moravě či v zahraničí. Patřili mezi ně např́klad Matyáš Borbonius (od 1609 v Praze), Simon Grynaeus (od 1600 v Olomouci), známý mj. provedením veřejné pitvy ženy v Brně 1594, Johannes Svenzel (po 1600 dolnorakouský lékař ve Vídni) či Matyáš Timin (od 1612 v Olomouci). Profesorem medicíny na univerzitě v Tübingen se pak v roce 1630 stal rodák z Velkého Meziř́ičí, někdejší městský lékař ve Stuttgartu, Jan Plachetius (1574-1635). ${ }^{38}$

Specifické jsou pak kariéry některých pobělohorských exulantů. Těm mohli při uplatnění v cizině napomoci také kontakty získané dříve a samozřejmě rovněž prestižní doktorát z Basileje. Již zmiňovaný Jan Škréta Šotnovský ze Závořic tak např́íklad díky stykům navázaným v době basilejských studií a zřejmě též sňatku s dcerou profesora filosofie a teologie Ludwiga Lucia našel uplatnění jako lékař v Basileji, od roku 1635 pak jako městský physicus v Schaffhausenu, $v$ kteréžto roli působil po řadu let až do své smrti v roce 1650.39 Podobně v městských službách ve Štrasburku našel uplatnění Nicolaus Parman z Prahy. 40 Jedním z dalších exulantů a doktorů medicíny basilejské univerzity byl také Matyáš Erbinaeus z Brandova, který našel ve 20. letech 17. století obživu nejprve v Uhrách, respektive v Sedmihradsku (léčil např. knížete Gábora Bethlena), později ve Slezsku ve službách Jana Kristiána Břžského. ${ }^{41}$

\section{Publikační činnost studentů medicíny v Basileji}

Na úvod tohoto oddílu bychom rádi předeslali, že stručné biografie a bibliografie basilejských tisků zde zmíněných studentů budou vydány v plánované publikaci vycházející z grantu GAČR, a nezatěžovali jsme jimi proto poznámkový aparát. Také basilejské tisky, jichž je v tomto oddílu naprostá většina, citujeme ve zkrácené formě autor-název-tiskař-rok. Pokud místem tisku nebyla Basilej, je tato skutečnost výslovně uvedena.

36 Ve švédských službách ve Stockholmu se uplatnil Johannes I. Richter z Opavy, získavší doktorát medicíny v Basileji 6. 9. 1597. Jako lékař Ernsta Fridricha Bádensko-Durlašského působil zase další Opavan, Valerius II. Polanus (kol. 1603).

37 K Behrnauerovi srov. G. F. Отто, Lexikon I, s. 83; Matrikel Basel II, s. 502; Robert SeIDEL, Späthumanismus in Schlesien. Caspar Dornau (1577-1631). Leben und Werk, Tübingen 1994, s. 235, 245, 247, 367, 417, 474.

38 K Plachetiovi viz alespon̆ Zacharias Schäffer, Oratiuncula, de vita atque obitu D. Johannis Plachetii, Tübingen: Geysler 1635; G. Gellner, Životopis lékaře Borbonia, s. 8; Matrikel Basel III, s. 37; RHB IV, s. $197 \mathrm{n}$. $\mathrm{K}$ dalším srov. jejich biogramy v připravované knize M. HolÝ a kol., Die Universität Basel und die böhmischen Länder im Spätmittelalter und der frühen Neuzeit.

39 J. H. ZedLer, Grosses vollständiges Universal-Lexicon XXXVI, Sp. 709n.; Ch. G. Jöcher, Allgemeines Gelehrten-Lexicon IV, Sp. 432; HBLS VI, s. 318; Matrikel Basel III, s. 225; RHB V, s. 279n.

40 K němu viz alespoň Matrikel Basel III, s. 200.

41 RHB II, s. 108; Vladimír KARPENKO, Matthäus Erbinäus von Brandau: alchymie mezi realitou a fantazií, in: Ivo Purš - Vladimír Karpenko (edd.), Alchymie a Rudolf II. Hledání tajemství přírody ve střední Evropě v 16. a 17. století, Praha 2011, s. 393-421; M. HoLÝ, Ve službách šlechty, s. 169. 


\section{1. Teze a disputace}

S jednotlivými fázemi studia medicíny, které mělo být zakončeno doktorátem, se pojily určité typy univerzitních publikací. Napřed měl student přednášku, ${ }^{42}$ poté požádal o připuštění $\mathrm{k}$ doktorátu a absolvoval zkoušky u některého $\mathrm{z}$ profesorů doma a poté ještě $\mathrm{v}$ grémiu na univerzitě. Následně dostal témata $\mathrm{k}$ disputaci, např. Matyáši Borboniovi byla sdělena na konci poslední zkoušky. Předem schválené teze (theses, positiones) nechal kandidát vytisknout spolu s předpokládaným datem disputace, rozvěsit na čtyři farní kostely v Basileji, bránu univerzity a poslat po pedelovi všem univerzitním doktorům a profesorům. Podle Fritze Husnera mohly mít teze i formu jednolistu. ${ }^{43}$ Většinou však se jednalo o kvartový formát $\mathrm{v}$ rozsahu od osmi do několika desítek stran.

Od podzimu 1575 musely být teze disputací vydávány povinně tiskem. ${ }^{44}$ Studenty z českých zemí mezi jejich autory nacházíme poměrně brzo, nejstarší známé teze jsou Jana Stodolia (1578) a následně Simona Florina (1579). ${ }^{45}$ Ze samostatných studentů medicíny, zkoumaných v tomto článku, doktorát v Basileji nezískalo pouze několik osob, ${ }^{46}$ to však neznamená, že zde nemohli konat cvičné disputace, jako např. Jan Emberiza. ${ }^{47}$

Tištěné kvartové teze se liší rozsahem a také doprovodnými texty, jejich rozsah závisel nejen na píli studenta, ale i na jeho finančních možnostech, ${ }^{48}$ zvláště zpočátku, později univerzita na tisk tezí někdy i finančně přispívala a uzavírala s tiskaři smlouvy, které regulovaly cenu tisku studentských tezí. ${ }^{49}$ Témata byla nejrůznější, od nejběžnějšího „de pleuritide“50 (Ungarus 1582, Grynaeus 1591, Svenzelius 1600), přes trávicí potíže, psychická hnutí (teze o hněvu Štěpána Štefka z Koloděj 1619) až k ženskému lékařství (např. Daniel Štyrkolský disputoval 1610 o prríliš silné menstruaci). To, že student zpracovával běžně zadávané téma, nesvědčilo nijak o jeho menších schopnostech, např. na téma De pleuritide hovořil při své doktorské disputaci i Marcin Chmielnik, pozdější basilejský profesor medicíny. ${ }^{51}$

42 R. Thоmmen, Geschichte der Universität Basel, s. 85nn., podrobněji tÝž, Basler Studentenleben im 16. Jahrhundert, Basler Jahrbuch 1887, s. 18-29, dle deníku Felixe Platera; podobné zprávy jsou také v deníku Matyáše Borbonia, viz G. Gellner, Životopis lékaře Borbonia, s. 50n. Borbonius disputoval dokonce dvakrát než se přihlásil ke zkouškám, obě disputace vydal tiskem. Po zkouškách disputoval „pro gradu“ a disputace trvala téměř čtyři hodiny. Měsíc nato se konala promoce.

43 F. Husner, Verzeichnis, s. 7. Z bohemikálního materiálu známe pouze jednolistové teze od Matyáše Timína z Ottenfeldu, člena žerotínské družiny, De respirationis usu z roku 1585.

$44 \mathrm{~K}$ tomu A. Burckhard, Geschichte der Medizinischen Fakultät, s. 156, F. Husner, Verzeichnis, s. 8, však nenašel žádné úřední doklady toho rozhodnutí. Kvalitním pramenem i pro teze našich studentů je konvolut UB Basel La I 11, jenž obsahuje 80 tezí od poloviny století do roku 1624. Basilejská knihovna navíc uchovává několik konvolutů Disputationum medicarum Basiliensium s více než šesti sty disputacemi. Jednu z největších sbírek tezí včetně těch basilejských má univerzitní knihovna Erlangen - Nürnberg.

45 F. Husner, Verzeichnis, s. 27; Matrikel Basel II, s. 252, 267

46 Platí to např́klad pro Jana Emberizu (získal snad doktorát v Montpellier), Ludwiga Keplera (v Padově), Caspara Cholia či Valeria II. Polana (u obou posledních doktorát nedoložen). Nejasná je situace u Daniela Stolcia, ve 30. letech doktorátu užíval, kde jej ale získal, není známo.

47 F. Husner, Verzeichnis, s. 50, 54.

48 Např́klad Jan Plachetius, o němž z korespondence víme, že byl chudý (viz list Jana Pressia Casparu Bauhinovi v UB Basel, G2 I 5:B1. 262), vydal své doktorské teze v minimálním možném rozsahu, jaký umožňoval kvartový formát, tedy na osmi stranách.

49 F. Husner, Verzeichnis, s. 16-17.

50 Také F. Husner, Verzeichnis, s. 21, označil toto téma za jedno z nejčastějších. Poznamenává k tomu, že termín pleuritis (dnes používaný pro zánět pohrudnice) označoval tehdy mnohem širší škálu dýchacích obtíží.

51 Tamtéž, passim (dle rejstř́ku). 
Po úspěšné disputaci bylo domluveno datum promoce a kandidát nechal vytisknout pozvánky. Ty začínaly obvykle invokací, následovalo jméno promotora, jméno kandidáta či kandidátů, někdy se objevuje také jméno rektora a děkana čili decuriona, jindy bývají jejich jména dopsána rukou. Pozvánka dále obsahovala také témata, o nichž měl kandidát před samotným slavnostním aktem promluvit. Ta mohl student sám navrhnout, jak to udělal např́íklad Daniel Pelikán z Opavy. ${ }^{52}$ Po proslovení řeči následoval obřad, při němž kandidát dostal sametový biret ozdobený věncem a doktorský prsten. Poté došlo na děkovnou řeč nového absolventa, schválenou dopředu promotorem.

Tištěných jednolistových pozvánek k promocím je pro období do roku 1604 dochováno pro naše studenty poměrně hodně v jenském sborníku. ${ }^{53}$ Nejstarší bohemikální pozvánka k lékařské promoci z roku 1578 je poněkud netypická, protože promoce Jana Stodolia z Požova byla oznamována zároveň s promocí tří doktorů práv. Pozoruhodná je i druhá nejstarší pozvánka z roku 1579 od Michaela Florina z Lambsteinu spolu se třemi dalšími studenty. Jeho promotorem byl Nicolaus Taurellus, jenž pozvánku ozdobil vlastní básní v sapfické strofě, oslavující obřad promoce a její symboly - doktorský biret, knihu a prsten. Básně promotorů nejsou v basilejských univerzitních tiscích té doby běžné, je pravděpodobné, že se zde Taurellus chtěl prezentovat jako nedávno jmenovaný profesor rétoriky. Rok nato však z Basileje odešel na altdorfskou akademii a v básních promotorů po něm nikdo nepokračoval. Obecně se dá říci, že basilejští profesoři medicíny se poezii spíše nevěnovali, to se změnilo až s nástupem Emanuela Stupana (1620), jenž pěstoval příležitostnou poezii v hojné míře. Pozvánky na promoce našich studentů tedy zůstávají v tradičním duchu s jednou výjimkou, a tou je neobyčejně zajímavá pozvánka na promoci Simeona Partlicia a dalších tří uchazečů o doktorský titul. ${ }^{54} \mathrm{~V}$ jejím středu pod textem pozvání stojí Partliciem vytvořený horoskop pro den promoce s výkladem, pod ním je vytištěna báseň basilejského poety laureata J. J. Grassera a Jana Škréty Šotnovského ze Závořic, obě na téma horoskopu (obr. 2).

Vrat'me se ještě k tezím a disputacím. Disputace byly většinou doktorské (disputatio pro gradu nebo inauguralis), mohly však být i cvičné (exercitii causa). Ty se konaly jednou za měsíc (exercitia menstrua) osmkrát do roka a později i desetkrát. ${ }^{55}$ Od roku 1577 bylo po cvičných disputacích podáváno i občerstvení jako již dříve běžně u disputací doktorských, aby se prritáhlo více diváků. ${ }^{56}$ Tiskem se tyto disputace vydávaly pro více respondentů dohromady, napřed dva, pak tři ${ }^{57}$ a začátkem 17. století až sedm. Obzvláštní rozvoj měsíčních disputací panoval za Johanna Nicolaa Stupana, jenž jim obvykle předsedal ve dvojici s Casparem Bauhinem. Disputace pak byly vydávány tiskem zvlášt’ nebo za každý uplynulý

52 V listu Casparu Bauhinovi prosí Pelikán o odložení daného data promoce a navrhuje téma, o němž bude disputovat (Štrasburk, 18. května 1621, UB Basel, G2 I 3:B1. 78).

53 Ve Forschungsbibliothek Gotha jsou dochovány tři sborníky chronologicky řazených tištěných pozvánek k promocím s rukopisnými dodatky, rozdělené podle fakult na teologickou, právnickou a lékařskou. My čerpáme nejvíce z Programmata medicinae omnium doctorum publice promotorum Basileae a religionis reformatione MDXXXII ad annum MDCIV inclusive, sign. Phil 2 00215/02 (03). Dostupné na $<\mathrm{https://dhb.thulb.uni-jena}$ .de/receive/ufb_cbu_00006448?lang=en> (13.6.2021).

54 Thomas Platter, Divino numine annuente, Genath 1621, jednolist.

55 Např. Joannes Nicolaus Stupanus, Pathologiae pars altera, Schroeter 1603, dedikovaná předmluvou Janu Katarýnovi z Kataru.

56 F. Husner, Verzeichnis, s. 11.

57 Např. J. N. Stupanus, Pathologiae pars prima, Schroeter 1601, v níž jsou mj. i teze Václava Kavína a Jakuba Behrnauera. 
rok, někdy docházelo i k pozdějším přetiskům. ${ }^{58}$ Tiskaři občas recyklovali z vlastního zájmu disputace za delší období, např. univerzitní tiskař Johann Jakob Genath ${ }^{59}$ vydal roku 1618 Decas disputationum medicarum, sborník, jenž obsahoval svázané starší disputace (včetně titulních listů a paratextů) opatřené tiskařovou předmluvou a doprovodnou básní. Datum disputace se často rukopisně měnilo nebo bylo v tisku rovnou vynecháno a doplněno rukou později. Někteří pozvaní se na disputace připravovali, jak dokazují vpisky a podtrhávání v textu. ${ }^{60}$

Otázka autorství doktorských tezí je obvykle složitá61 a těžko se rozlišují autorské podíly studenta a dohližejícího profesora. Podle zmínek v korespondenci můžeme soudit, že námi zkoumaní studenti medicíny byli většinou cílevědomí a iniciativní a teze vypracovávali relativně samostatně, prritom samozřejmě s profesory konzultovali a také si od nich půjčovali odbornou literaturu. $V$ některých př́padech mohou mít teze krátký úvod (instituti ratio, praefatio ${ }^{62}$ ), velmi stručný doslov a na závěr citát z nějaké lékařské autority. ${ }^{63}$ Struktura $\mathrm{v}$ očíslovaných bodech se zachovává, $\mathrm{k}$ nim přidaný text může být psán heslovitě nebo může obsahovat i několik souvisle psaných odstavců. Od počátku 17. století bývají na samotném závěru tezí dodatečné další probírané otázky a doplňky (quaestiones ... superpondii loco či parerga) nebo častěji závěrečné shrnutí práce a základní otázky v bodech (corollaria). ${ }^{64}$

\section{2. Paratexty publikovaných tezí}

Specifický předmět výzkumu představují paratexty doprovázející tištěné teze, a to dedikace a průvodní básně. Dedikace měly různé formy: mohly být včleněny př́ímo do názvu disputace na titulním listu ${ }^{65}$ nebo stály samostatně na začátku bud' jako dedikační listy, ${ }^{66}$ později spíše jako věnovací předmluvy. Dedikační listy mívaly osobnější ráz, zatímco v předmluvách převažovaly obecné úvahy, které ovšem v druhé polovině nutně obsahovaly i pochvalnou zmínku o osobě, jíž byla předmluva věnována. I zde se najdou výjimky, např́klad předmluva Jana Emberizy, ${ }^{67}$ která začíná obřadným oslovením Adama Erdmanna Trčky z Lípy, syna jeho pána Jana Rudolfa Trčky, pokračuje popisem dobrodiní, které Trčka prokázal autorově rodině a jemu samému, aby postupně přešel k poděkování dalším svým podporovatelům včetně básníka Jiřího Carolida. Rétoricky rozvinutý závěr pak patří opět Trčkovi a jeho otci. Pohnuté období po Bílé hoře odráží svým osobnějším tónem dedikace

58 J. N. Stupanus, Prolegomena medica, Schroeter 1608 (s disputacemi C. Cholia a J. Emberizy) znovu jako Medicina theorica, Schroeter 1614.

59 J. J. Genath starší byl prvním oficiálním univerzitním tiskařem (academiae typographus), a to od roku 1615.

60 Např. u tezí Simona Grynaea v UB Basel, sign. Diss. 25:3.

61 F. HuSNER, Verzeichnis, s. 14.

62 Např. Ondřej Habervešl z HaBernfeldu, Theoremata de uroscopia, Genath 1609.

63 V Kavínově disertaci nacházíme všechny tyto tři součásti, na počátku stojí instituti ratio, po tezích následuje bez nadpisu závěr a na poslední straně citát z Galéna, pod nímž je vytištěna invokace (Soli Deo gloria).

64 Např. u tezí Caspara Cholia, De morbo Ungarico, Schroeter 1607.

65 Věnování doktorské disputace Matyáše Timína Václavu Lavínovi roku 1597.

66 Tento typ se používal ve starším období, př́ikladem může být list Jana Stodolia Tomáši Husineckému, který zachovává formální náležitosti typické pro korespondenci a zpravuje adresáta o svých studijních cestách, pobytu v Basileji a doktorské zkoušce, aby mu nakonec ohlásil svůj brzký návrat domů. (J. STodoLius, Theses, Ostenius 1578).

67 Jan EmBeriza, Problematum medicorum decades tres, Genath 1610. 
tezí Ludwiga Keplera pro Albrechta z Valdštejna, jenž jeho otce Jana Keplera přijal do svých služeb a podporoval vydání jeho astronomických prací. 68

Ačkoli to byla forma v okruhu pražské univerzity běžná, ve zkoumaných basilejských tezích prakticky nenarazíme na veršovanou dedikaci. ${ }^{69}$ Naopak pro svou stručnost a působivost byla oblíbená forma nápisu, typograficky výrazného centrovaného textu většinou na rubu titulního listu. ${ }^{70}$ Ta se používala obzvláště často v př́padě, že autor dedikoval více osobám. ${ }^{71}$ Teze byly obvykle věnovány učitelům, at' už se jednalo o české a moravské lékaře, kteří se o studenta starali před jeho odchodem na studia, nebo samotné profesory basilejské univerzity. Dále jsou mezi adresáty mecenáši ze šlechtických i měšt’anských kruhů, někdy i celé městské rady. ${ }^{72}$

Pokud student vydal více disputací, dá se říci, že dedikace byly odstupňovány podle vážnosti a podle finanční závislosti dedikujícího. Jako příklad můžeme uvést opavského studenta medicíny Johanna Richtera. Ten věnoval první cvičnou disputaci opavskému lékaři Václavu Raphanovi, druhou svému př́íbuznému Amandu Polanovi, lékaři Petra Voka z Rožmberka Matyáši Timinovi a lékaři Žerotínů Janu Lojkovi. Poslední, doktorskou disputaci pak určil Richter svému otci, jenž jeho studium financoval. Větší nezávislost samostatných studentů ve srovnání např́íklad se šlechtickými preceptory dokazuje fakt, že dedikace $\mathrm{v}$ jejich tezích v některých případech chybí ${ }^{73}$ nebo dedikují své teze Bohu. ${ }^{74}$

Průvodní básně pro teze, gratulační básně a řidčeji také doprovodné básně na pozvánky $\mathrm{k}$ promoci psali přátelé, spolubydlící (commensales, contubernales) nebo spolukandidáti (competitores) uchazečů o doktorskou hodnost, v mnohem menší míř kandidáti sami. Básně od profesorů nebyly, jak jsme už konstatovali výše, na rozdíl od zvyklostí pražské univerzity častým jevem. V tezích bývaly básně otiskovány nejčastěji na konci, ${ }^{75}$ aby se využily prázdné stránky, méně často na počátku tisku za dedikací. Od počátku 17. století se problém zbývajících prázdných stran řešil také tím, že se tam otiskly závěrečné body tezí (corollaria).

O kvalitě této poezie se Husner vyjadřuje poněkud s despektem, podle něho byla většina těch básní tak neumělá, že by je dnes nikdo neotiskl, ale občas je možné překvapivě

68 Ludwig KEPLER, Anthropologia seu genealogia de principiis foetus, Schroeter 1630.

69 Matyáš Borbonius napsal dedikační verše Simonu Grynaeovi, tehdy již lékaři v Brně, do své cvičné disputace De febre tertiana, Waldkirch 1596. Jedno neumělé distichon do svého dedikačního nápisu pro Oldřicha z Kounic vložil pro ozdobu Václav Kavín, Agón iatrikos, Schroeter 1601.

70 Př́ikladem může být dedikace Michaela Florina Gryspekům z Gryspachu nebo Simona Grynaea Matyáši Žlutickému, z pozdějších např. dedikace Štěpána Štefka z Koloděj jeho otci Tobiášovi, členu sboru defensorů, nebo Simeona Partlicia Abrahamu Scultetovi a členům pražské konsistoře Havlu Faethónovi Žalanskému a Janu Korvínovi.

71 Např. Václav Kavín věnoval basilejským profesorům svou cvičnou disputaci Doctrina de humoribus roku 1597.

72 Např. Michael Ungarus či Daniel Pelicanus dedikovali opavským konšelům.

73 Kromě již zmíněného Timínova jednolistu se s tím setkáme např́klad u kvartové doktorské disputace Jakoba Behrnauera, De fluxionibus, Schroeter 1602, u doktorské disertace Daniela ŠtyrkolskéHo z Volovic, De menstruorum fluxu, Schroeter 1610, nebo u Ondřeje HaBERVEŠLA z HaBERnFELdU, Theoremata, Genath 1610, či Georgia JudEXE, De scorbuto, Schroeter 1624.

74 Nicolaus Parman, Problemata medica, Genath [1618].

75 Např. Janu Menceliovi z Prahy napsal průvodní báseň jeho krajan Jan Emberiza a jeho spolubydlící, Skot Patricius Dunaeus (Disputatio medica de ascite, Schroeter 1607). 
narazit na lepší kvalitu. ${ }^{76}$ Kromě běžných školských výtvorů, které se př́liš neliší jeden od druhého, můžeme objevit formálně i obsahově kvalitní díla, jež obvykle nezaprou osobnost autora, at' už je to ze zahraničních básníků Matthias Zuber, či Michael Maier, z českých pak Jan Škréta Šotnovský ze Závořic (k němu viz níže).

Podíváme-li se na to, jak účast $\mathrm{v}$ příležitostných publikacích vypovídá o osobních kontaktech jednotlivců, musíme konstatovat, že samostatní studenti medicíny se až na výjimky neobjevují jako přispěvatelé v publikacích členů šlechtických výprav, zůstávají ve skupině svých spolubydlících z různých zemí či krajanů, dalších samostatných studentů (např. Emberiza, Cholius a Mencelius). Přispívají však do tisků jiných zahraničních studentů z německých zemí, Polska či Anglie a na oplátku zdobí své tisky básněmi od nich. Většinou se jedná o průměrnou poezii psanou tehdy nejpoužívanějším veršovým rozměrem elegickým distichem, mezi její tvưrce patří Václav Kavín, Jan Emberiza, Štěpán Štefek z Koloděj nebo Ludwig Kepler, někteří básníci však používají i složitější strofické útvary (Matthias Erbinaeus a zejména Jan Škréta). Kromě oslavy kvalit kandidáta a přání dlouhého věku, což je topos, který v gratulačních básních obvykle nechybí, můžeme v básních najít údaje o jeho předchozím studiu, chválu basilejské univerzity a jejích profesorů, ${ }^{77}$ nebo verše vztahující se k tématu disputace. ${ }^{78}$ Častým motivem je boj (agón), který podstupují kandidáti, aby získali Apolónův vavřín, jindy je to lod' doplouvající do klidného př́stavu, symbolizujícího doktorský titul, který svému nositeli zaručuje život v dostatku. Zř́́dka se vyskytují básnické hřŕčky, jako je chronostich s datem promoce, ${ }^{79}$ na počátku 17 . století se častěji objevuje anagram na jméno kandidáta. ${ }^{80}$

\section{3. Gratulační sborníky}

K publikacím spojeným se studiem medicíny patří také gratulační sborníky k doktorským promocím. Nejstarší byl uspořádán pro Lucase Gillera, zámožného studenta z Opavy v roce 1604, další tř̀i dochované sborníky jsou pozdější, z poměrně krátkého období let 1619-1622. Typově se jedná ve dvou př́padech o sborníky, které napsali krajané oslavence a jejich přátelé, $v$ dalších dvou pak o publikace, do nichž přispěli studenti z nejrůznějších zemí, s nimiž se adept doktorského titulu seznámil až v Basileji. Jestliže jsme výše konstatovali, že námi sledovaní jedinci obvykle nepřispívali do sborníků členů šlechtických výprav, naopak to tak zcela neplatí. Ve dvou gratulačních sbornících jsou totiž zastoupeni čeští či moravští šlechtici a preceptoři. Nemáme zatím žádné informace o tom, zda sborníky sestavoval pro oslavence někdo jiný nebo naopak on sám nechal vytisknout původně rukopisné gratulační

76 F. Husner, Verzeichnis, s. 19: „Die meisten dieser Gelegenheitsgedichte sind freilich so unbeholfen, daß sich heute kaum jemand entschließen würde, sie zu drucken; aber überrascht stößt man doch dann und wann auf Besseres."

77 Matthias Erbinaeus, Ode gratulatoria pro Christiana Rumpfa z Belgie (Theses medicae, Schroeter 1608), připomíná jeho studia u Scaligera, Clusia a dalších zahraničních profesorů, aby pak plynule vyjmenoval profesory basilejské - Platera, Zwingera, Stupana a Bauhina.

78 Jan Emberiza přispěl do tezí o epilepsii Fridricha SPIESE (Themata medica de epilepsia, Schroeter 1608) závěrečnou básní, v níž přítele stylizuje do role bojovníka proti Herkulově nemoci, jenž musí nasadit všechny zbraně, aby zvítězil a získal zaslouženou odměnu (= doktorský titul).

79 Napsal si je snad sám autor Jan Svenzel (Svenzelius) do tezí Noscendae et curandae pleuritidis etc., Schroeter 1600 .

80 Jan Škréta zveršoval v gratulačním sborníku anagram jména Daniela Pelicana (In Pallade vinces) a dalších zahraničních studentů. 
básně, které k promoci dostal. Druhá možnost je dost pravděpodobná už proto, že v případě všech čtyř adeptů doktorského titulu se jednalo o dobře situované jedince, navíc je zde analogie s tiskem epithalamií. ${ }^{81}$

Lucas Giller byl př́ibuzným Amanda Polana, jenž je snad také pořadatelem gratulačního sborníku Laurea Apollinea. ${ }^{82}$ Sám Polanus také přispěl gratulační latinskou básní, za ním řeckou v hexametrech Jacob Zwinger. Na předním místě ovšem stojí tři disticha šlechtice mladého Jaroslava Smiřického ze Smiřic. Mezi přispěvateli nechyběl jeho preceptor Caspar Dornavius a další šlechtičtí preceptoři - Fridrich Pierius a Polák Jerzy Lemka, slezský poeta laureatus Caspar Cunradus a několik dalších přispěvatelů. Obsah gratulačních básní je konvenční, je oslavován původ adresáta a jeho učenost, jíž přeje Apolón i Múzy, verše však nepodávají bližší svědectví o Gillerovi a vztahu gratulantů k němu. V básni Johanna Bochmanna z Elbingu najdeme poměrně vzácný motiv dubového věnce, ${ }^{83}$ alternativu doktorského vavř́nu.

Gratulační sborník k promoci Štěpána Štefka z Koloděj Laurus Apollinaris ${ }^{84}$ je ukázkou pestrého složení studentů, kteří přicházeli do Basileje studovat medicínu - veršovanou gratulací přispěli Štefkovi přátelé z Polska, Dánska, Západního Fríska, Holandska, Vestfálska a Brém. Jediný autor z Čech by se snad mohl skrývat pod iniciálami M. P. S. B. (= Bohemus) u anagramu na Štefkovo jméno, s takovými iniciálami však v té době žádný Čech v Basileji nestudoval, mohlo jít spíše o někoho ze samotné Basileje nebo např́klad z Brém. V konvenčních projevech zaznívají místy i jiná témata, např́klad Samuel Czaplinius, jemuž Štefek na oplátku přispěl do jeho sborníku, připomíná př́ibuznost Čechů a Poláků v osobách jejich praotců Čecha a Lecha. ${ }^{85}$

Dalšímu studentu z Opavy, chráněnci Jana ml. Bruntálského z Vrbna a opavské městské rady, Danielu Pelikánovi byl věnován sborníček Votivi adplausus supremae laureae. ${ }^{86}$ Přední místa v něm opět zaujímají dva mladí šlechtici - Jan a Bartoloměj ze Žerotína spolu se slezským rytî́rem Janem z Czetritz. Dále jsou zde zastoupeni výrazní básníci ze slezského a lužického okruhu, především Michael Bartsch ${ }^{87} \mathrm{~s}$ pozoruhodnou metrorytmickou skladbou s refrénem nebo Paulus Gnilius, učitel štrasburského gymnázia s obsáhlou gratulací zahrnující chválu Basileje a jejích profesorů i Pelikánova původu. Ve Štrasburku byl Pelikánovým žákem tamní rodák Robert Königsman, jenž je také autorem neumělé poslední básně sborníku, dedikované „praeceptori suo olim carissimo“.

Poněkud odlišný od ostatních je gratulační sborník k doktorské promoci pro Jana Škrétu Šotnovského ze Závořic Laurus medica. ${ }^{88}$ Tento sborník dobře ukazuje Škrétovo zakotvení ve společnosti basilejských učenců. Uspořádal jej pravděpodobně univerzitní tiskař Genath, básněmi přispěli profesoři Emanuel Stupanus a Ludwig Lucius, s jehož dcerou se

81 Např. Borbonius napsal v Basileji epithalamia Polanovi a Zwingerovi, zatímco první nechal to svoje vytisknout, epithalamium druhého zůstalo v rukopise (G. GelLner, Životopis, s. 40).

82 Laurea Apollinea ... praestantissimo viro Dn. Lucae Gillero, Waldkirch 1604. Ke Gillerovi viz alespoň J. H. Cunradus, Silesia togata, s. 94; RHB II, s. 218.

83 Tato tzv. corona quercea se v antice získávala za záchranu životů a v raném novověku se s dubovým věncem nechávali zobrazovat lékaři, u nás např. Vavřinec Špán.

84 Laurus Apollinaris... decantata a fautoribus et amicis, Schroeter 1619.

85 Tamtéž, fol. A3a: Grande decus capiant ex te Czechicusque nepotes / et Lechi fratres.

86 Votivi adplausus supremae laureae in arte Asclepiadea ... Dn. Danieli Pelicano, Genath 1621.

87 O něm více John R. Flood, Poets laureate, De Gruyter 2011, s. 31-37; RHB I, 167; RHB VI, 53. V Praze byl žákem Jana Matyáše ze Sudetu, laureován v Basileji J. J. Grasserem roku 1618.

88 Laurus medica .... decantata ab amicis et fautoribus, Genath 1622. 
Škréta později oženil, dále Škrétův competitor Matthäus Brengger z Augsburku a student J. C. Fausius z Neuhausenu. Sborníček uzavírá básnickou gratulací a chronostichem s rokem promoce ${ }^{89}$ sám tiskar̆ Johann Jakob Genath. Jedná se o ukázku kvalitní př́iležitostné tvorby, autoři sice zakomponovali „povinná témata“, tj. vzdávají hold Škrétovým dovednostem a přejí mu dlouhý život, ${ }^{90}$ ale přecházejí i do osobní roviny (např. Ludwig Lucius piśe o Škrétově exilu jako o ztrátě vlasti, kterou má alespoň částečně vyvážit doktorský titul). Znovu se opakuje motiv lékaře jako rytiře Apollónova, jenž poráží nemoc: „Jako statečný rytír Apolónův se chápeš zbraní a bojuješ jimi ve dne v noci, zbraněmi, jimiž se z těla vyhání různé nemoci a nemocným se vrací síla a svěžest."

\section{4. Významní básníci mezi studenty medicíny, jejich basilejské laureace}

Kromě studentů, kteří psali poezii jen $\mathrm{v}$ rámci nutnosti, jsou mezi adepty lékařství z českých zemí i pozoruhodní básníci, jejichž př́tomnost $\mathrm{v}$ Basileji spadá do doby krátce po Bílé hoře. Jedná se zejména o právě zmíněného Jana Škrétu Šotnovského ze Závořic, bratra maliře Karla Škréty. Jeho básnická tvorba byla zatím spíše opomíjena, ${ }^{2}$ byt' jako zakladatel lékařské dynastie v Schaffhausenu není v literatuře zcela neznámý. Za svého pobytu v Basileji mezi léty 1621-1631 napsal Škréta desítky básní do tezí a gratulačních sborníkủ vydaných v Genathově univerzitní tiskárně ${ }^{93}$ a svými verši doprovodil vydání literárních děl basilejských učenců. Je také autorem distich na portrétu profesora hebrejštiny Johanna Buxtorfa (1629). Jeho básně jsou pozoruhodné nejen kvantitou, ale také svým obsahem - s náměty pracoval Škréta podobně jako pražský profesor Jan Campanus, hledal vždy téma, které je pro adresáta básně př́značné, nebo nějaký neotřelý motiv, a ty pak originálně zpracoval. Také po stránce formální je výjimečný: jeho favorizovaným rozměrem byl jambický senár, užíval také horatiovská metra. Jako básník byl ve své době v Basileji oblíbený a uznávaný a je třeba se divit, proč nezískal titul poeta laureatus. Znal se mimo jiné s jediným basilejským palatinem, který by mu mohl titul udělit, s J. J. Grasserem, jemuž např́íklad napsal průvodní verše pro jeho překlad Kroniky Valdenských ${ }^{94}$

Johann Jacob Grasser byl výraznou a nevšední osobností kulturního prostředí Basileje. Tento kněz a zároveň poeta laureatus navíc za studií v Itálii získal hodnost comes Palatinus, a mohl tedy kromě jiného sám korunovat básníky. ${ }^{95}$ Byl také ve spojení s basilejskou univerzitou, jeho verše nacházíme $\mathrm{v}$ jejích matrikách na počátku jednotlivých rektorských

89 TypographIa fVtVra artIVM DeCVs (=1622).

90 Obojí najdeme v úvodní básni Emanuela Stupana, jenž oslavuje Škrétovu znalost lékařství, filosofie, poezie a hudby a přeje mu dlouhý život neotřelým „frustreris saepe Charonta“.

91 „Strenuus interea Tu miles Apollinis arma / corripis et versas nocte dieque manu / Arma, quibus varii pelluntur corpore morbi, redditur atque aegris vividus usque vigor."

92 RHB V, s. 279-280. Pochvalnou zmínku čteme u Petera Buxtorfa, Alma mater poetica, Studien zur Geschichte der Wissenschaften in Basel IX, Basel 1960, s. 76-77; o motivech Rýna u Śkréty Elisabeth WEBER-REBER, Trauer und Repräsentation. Der Rhein als poetische Landschaft in Basels neulateinischen Epicedien des 17. Jahrhunderts, in: Carmen Cardelle de Hartmann - Ulrich Eigler (Hgg.), Latein am Rhein, Berlin - Boston 2017, s. 177-178, 183-184.

93 Nabízí se úvaha, že zde mezi Genathem a Škrétou šlo o vzájemně výhodnou spolupráci.

94 J. P. Perrin - J. J. Grasser, Waldenser Chronick, Wagner 1623.

95 Hanspeter MARTI, Grasser, Johann Jakob, in: Frühe Neuzeit in Deutschland 1520-1620. Literaturwissenschaftliches Verfasserlexikon (VL 16), III, De Gruyter 2014, sl. 63-67 (zde i starší literatura); J. R. Flood, Poets laureate, s. CXXVII-CXXVIII, s. 707-716. 
období. Krátce po Bílé hoře ověnčil básnickým vavřínem dva české adepty lékařství Simeona Partlicia a Daniela Stolcia. Pro oba se dochovaly Grasserovy laureační básně: Partlicius je vydal ve svém pozoruhodném díle Triumphus astrologiae, ${ }^{96}$ Stolciova laureace je dokumentována v jeho vlastním památníku autografy básní palatina Grassera, profesora rétoriky Ludwiga Lucia (obr. 3) a krajana Jana Škréty. ${ }^{97}$ Zatímco pro Partlicia se mnoho dokladů básnické činnosti nedochovalo a známe jedinou jeho gratulační báseň tištěnou v Basileji ${ }^{98}$ Stolciova básnická tvorba byla originální a známá, a přestože v Basileji dlouho nepobyl, stačil přispět průvodní básní do Grasserova Itineraria a napsat verše k Merianovým grafikám čtyř ročních období. ${ }^{99}$

\section{5. Další literární činnost a korespondence studentů s basilejskými profesory}

Mimo př́ležitostnou poezii a univerzitní tištěnou produkci nevydávali samostatní studenti v Basileji prakticky žádnou jinou literaturu. $Z$ tohoto pravidla se vymykají dvě díla, jednak zmíněný Partliciův Triumphus astrologiae, ${ }^{100}$ dialog mezi zastáncem a odpůrcem astrologie, a Thesaurus Rulandinus, vydání lékařských prací Martina Rulanda, jež připravil Jan Škréta Šotnovský ze Závořic spolu se svým spolužákem ze studií Georgem Spörlinem z Basileje. ${ }^{101}$ Edici věnovali svým patronům, polským šlechticům Andrzeji a Rafaelovi z Lešna, iniciátorem byla tiskařská rodina Henricpetri. Škréta se Spörlinem vydali v jednom svazku Rulandovu sbírku lékařských př́ípadů Curationes empiricae ${ }^{102}$ a tři jeho traktáty. U Curationes editoři přepracovali členění textu a namísto podle kapitol jej členili podle nemocí a v jejich rámci číslovali jednotlivé postupy. Ačkoli v předmluvě skromně píší, že změny oproti předchozímu vydání může čtenář posoudit sám, ${ }^{103}$ při srovnání obou edic je vidět, že významně zasahovali i do textu, který přepracovali a rozšrírili. Oblibu tohoto vydání dokazuje pozdější přetisk v Budyšíně, označený už jako „editio tertia“. 104 Původně

${ }^{96}$ Triumphus astrologiae, Schroeter 1621.

${ }^{97}$ UB Uppsala, sign. Y 132 d, fol. 213r-214v, 330v-331r. O štambuchu Heike HiLd, Das Stammbuch des Medicus, Alchemisten und Poeten Daniel Stolcius als Manuskript des Emblembuches Viridarium Chymicum (1624) und als Zeugnis seiner Peregrinatio Academica, München 1991 (netištěná disertace); Wilhelm KüHLManN, Poeta, Chymicus, Mathematicus. Das Stammbuch des böhmischen Paracelsisten Daniel Stoltzius von Stoltzenberg, in: Joachim Telle (Hg.), Parerga Paracelsica. Paracelsus in Vergangenheit und Gegenwart (Heidelberger Studien zur Naturkunde der frühen Neuzeit 3), Stuttgart 1991, s. 277-300.

98 Přispěl do gratulačního sborníku J. DeETzIA, Vota gratulatoria, Genath 1621.

99 J. J. Grasser, Itinerarium, König 1624; k Merianovým grafikám Lucas H. WüTHRICH, Das druckgraphische Werk von Matthäus Merian d. Ä, I, Basel 1966, č. 376-379.

100 Více RHB VI, s. 228. O Partliciovi a jeho obranách astrologie Vladimír URBÁneK, Eschatologie, věděni a politika: přispěvek $k$ dějinám myšleni pobělohorského exilu, Praha 2008, s. 79-82.

101 Thesaurus Rulandinus, Henricpetri 1628. Georg Spörlin (1582-1629) byl basilejský lékař a od roku 1628 profesor praktické filosofie na tamní univerzitě. Detaily o jeho životě podává Theodor ZwingeR, Christliche Leichpredigt, Wagner 1629.

102 Sebastian Henricpetri vydal Curationes empiricae poprvé za Rulandova života roku 1593 s dedikací autora Vilému z Rožmberka, do roku 1610 následovalo ještě několik vydání v téže oficíně s nezměněnými paratexty. Roku 1610 vydal Henricpetri Curationes v malém př́ručním formátu v deseti svazcích, edičně připravených Martinem Rulandem mladším z vydání v Lauingen 1578, v roce 1627 pak samostatně Tractatus tres (de phlebotomia, de scarificatione, de ortu animae), aby vše o rok později sjednotil ve svazku Thesaurus Rulandinus. O Curationes viz Ivo PURŠ - Josef SMOLKA, Martin Ruland starši a mladši a prostředí císařských lékařù, in: Alchymie a Rudolf II., Praha 2011, s. 590-591.

${ }^{103}$ Fol.):(3b: „Reliqua, quae praestitimus, collatio Antiqui et huius nostri Exemplaris te docebit.“

104 Thesaurus Rulandinus, Budyšín: Richter 1679-1680. 
Škréta se Spörlinem plánovali vydat ještě další svazek o lécích (Medicamina), nejen podle Rulanda, tento záměr však zřejmě zhatila Spörlinova předčasná smrt.

Za svým způsobem literární pramen se dá považovat i dochovaná latinská korespondence studentů s basilejskými profesory. Dopisy zachované v Univerzitní knihovně v Basileji přinášejí navíc mnoho informací o životě studentů, jejich cestě za vzděláním, vztahu k profesorům a dalším vývoji jejich kariéry. Jedná se o různé druhy listů, od rétoricky zaměřených či odborných lékařských (epistolae medicinales) až po běžné informativní dopisy, jaké známe z dnešní doby. Zvláštní druh představuje doporučující list (epistola commendatoria). Ten byl nezbytným vybavením studenta, jenž přicházel z cizí země do Basileje. V našem korpusu jich máme hned několik: dopis, v němž Stodolius doporučuje Theodoru Zwingerovi Simona Florina, list lékaře arcivévody Ferdinanda Jana Willebrocha, jímž Zwingerovi rekomenduje svého syna (obr. 4), ${ }^{105}$ doporučující list Caspara Dornavia pro Štěpána Štefka z Koloděj nebo list Jakoba Behrnauera, jenž Casparu Bauhinovi doporučuje studenta z kraje, v němž působil. 106

Doporučující listy obvykle obsahují informace o původu a dosavadním studiu adepta a jsou tedy vítaným zdrojem biografických informací. Z korespondence se dozvídáme i o dalších osobách, které měly vliv na život studentů v Basileji. Jako příklad může sloužit v naší literatuře dosud opomíjený lékař a botanik Johann Heinrich Cherler, ${ }^{107}$ zet' Bauhinova bratra Jana, zemského lékaře v Montbéliardu. Cherler byl patronem Johanna Svenzelia, jehož poslal na cestu do Heidelberku za tamním dvorním lékárníkem Nicolaem Sprengerem, 108 a o jeho smrti v Paříži v ř́íjnu 1605 napsal Casparu Bauhinovi Jan Pressius, preceptor Matyáše Žalkovského ze Žalkovic. ${ }^{109}$ Cherlerovo jméno se objevuje i v dalších listech šlechtických preceptorů.

Ve zkoumaném materiálu se nachází několik listů našich studentů Theodoru a Jacobu Zwingerovi, naprostá většina je však adresována Casparu Bauhinovi. Ačkoli jej Burckhardt charakterizoval jako muže uzavřeného a nepř́liš laskavého, ${ }^{110}$ listy studentů o tom nesvědčí. Naopak je z nich možné vycítit kladný poměr Bauhina ke studentům - psal jim doporučující listy pro své kolegy na univerzitách v Padově či Montpellieru, finančně je podporoval, oni s ním konzultovali své práce, obstarávali mu v zahraničí odbornou literaturu a předávali jeho dopisy. $V$ jednom prípadě dokonce Bauhin dedikoval jednomu studentovi, Nicolau Parmanovi z Prahy, svou knihu. ${ }^{111}$ Z Parmanových entuziastických dopisů, psaných $\mathrm{v}$ krátkých intervalech po sobě, je dobře znát jeho nadšení $\mathrm{z}$ této pocty a nedočkavost, kdy už kniha, obsahující v dedikaci jeho jméno, vyjde. ${ }^{112}$

105 UB Basel, Frey-Gryn Mscr I 11, fol. 84. Willebroch neposlal Zwingerovi, s nímž jej pojila přátelská kolegialita, jen tento dopis. Poté, co se syn vrátil z Basileje s doktorátem, mu napsal ještě poděkování za jeho pomoc (Frey-Gryn Mscr I 11:B1.85). Z tohoto listu je patrná jeho nespokojenost se životem na dvoře arcivévody Ferdinanda, stěžuje si na špatné finanční ohodnocení a neúctu svého zaměstnavatele ke vzdělání.

106 Dornavius: UB Basel, G2 I 3, fol. 12; Behrnauer: tamtéž, G2 I 2:B1. 417-418.

107 Viz G. Gellner, Životopis, s. 40, pozn. 1; A. Burckhard, Geschichte der Medizinischen Fakultät, s. 133.

108 UB Basel, Frey-Gryn Mscr I 14:Nr.127.

109 UB Basel, Frey-Gryn Mscr II 18, č. 132. K Pressiovi viz i s dalšími odkazy M. HolÝ, Ve službách šlechty, s. 262 n.

110 A. BuRCKHARDT, Geschichte der Medizinischen Fakultät, s. 98.

111 Caspar Baunin, De remediorum formulis Graecis, Frankfurt/M.: Jacobus 1619. Na rubu titulního listu dedikace: Praestantissimo et doctissimo domino Nicolao Parman Pragensi Boemo Philosopho et Medico et in facultat. medicam quae Basileae est cooptato, libros hosce duos ... Caspar Bauhin ... amoris monument. ... offert.

112 UB Basel, Frey-Gryn Mscr II 18, č. 61-62; G2 I 5, fol. 229-231. 
Vzájemná výměna dopisů však obvykle netrvala dlouho, snad s výjimkou Jacoba Behrnauera, jenž pro Bauhina vyřizoval jakousi finanční záležitost ve Slezsku a psal si s ním mezi léty 1616-1624. ${ }^{113}$ Mnoho studentů, s nimiž si korespondoval, se zapsalo i do Bauhinova památníku. ${ }^{114}$ Některé zápisy byly pořízeny $\mathrm{v}$ den doktorských promocí, na něž památník zřejmě nosil ( $\mathrm{k}$ nim si vlastnoručně připisoval jméno promotora, rektora a děkana), jiné před odjezdem studentů z Basileje. Z českých či moravských studentů medicíny, z nichž někteří měli také svá alba amicorum, ${ }^{115}$ se mu zapsali: Simon Grynaeus (fol. 79r), Johann Richter (fol. 62r), Václav Kavín (88r), Johannes Svenzelius (fol. 98r), Jakob Behrnauer (fol. 87v), Lucas Giller (fol. 62v) a Jan Plachetius (fol. 133r). Zápisy kromě obvyklé porce lichocení (všichni Bauhinovi životopisci až na Burckhardta ${ }^{116}$ se shodují $\mathrm{v}$ tom, že byl velmi ješitný) vyjadřují upř́mnnou vděčnost studentů a jejich obdiv $\mathrm{k}$ svému učiteli. Charakteristický pro smysl lékařské profese je zápis Johanna Svenzelia: „Boha se bát a uctívat ho, sama sebe znát a milovat, bližnímu činit dobře a podle svých schopností sloužit" ${ }^{\circ 117}$ (obr. 5 a 6)

\section{Závěrem}

Ačkoli nebylo možné v předkládané studii postihnout všechna možná témata, podařilo se zřetelně poukázat na význam basilejské univerzity pro studenty medicíny z českých zemí, kteří v pozdním 15. století, stejně jako po celou předbělohorskou dobu, respektive i další decennia 17. století (obnovení lékařské fakulty pražské univerzity si vyžádalo určitý čas), nemohli takové studium absolvovat $\mathrm{v}$ českých zemích. U většiny osob, u nichž bylo možné ve větší či menší míře díky dochovaným pramenům zkoumat jejich geografickou, sociální i konfesní skladbu, stejně jako vzdělanostní profil, bylo studium spojeno se ziskem doktorátu, který výrazně akceleroval jejich kariéry. I ony se staly předmětem výzkumu předkládané studie. Jasně se pak ukázala prestiž basilejské univerzity, jež mnoha z nich umožnila zakotvit profesně nejen v českých zemích, ale také v zahraničí.

Vliv studia ve Švýcarsku se ovšem projevil také v dalších oblastech, at' již se to týká navázaných a někdy dále rozvíjených kontaktů, konfesijního přesvědčení zkoumaných jedinců, jejich literární tvorby apod. Podrobné studium dochovaných basilejských tisků zkoumaného období prokázalo, že se studenti z českých zemí zapojili do standardní publikační činnosti basilejské univerzity, v rámci studia vydávali tiskem teze svých disputací, at' už mimořádných, nebo doktorských. Jejich paratexty nám poskytují širokou škálu informací o společenském zakotvení studentů, o jejich kontaktech, vazbách na basilejské prostředí, na jednotlivé konvikty či na konkrétní šlechtické výpravy. Podobně je možné vytěžit

${ }^{113}$ Známe ale příklady studentů, jejichž korespondenční styk s Bauhinem byl plodnější, například preceptor Diviše Lacemboka Slavaty Slezan Johann Weidner si s Bauhinem dopisoval v letech 1602-1614, přičemž šlo o více než jen zdvořilostní korespondenční výměnu.

114 UB Basel, sign. AN VI 16.

115 Dochovalo se však, pokud víme, jen album Daniela Stolcia.

116 Pravdu má ovšem Burckhardt, když píše: „...desgleichen ist es nicht unbedingt ein Zeichen von Eitelkeit, wenn er in seinen Schriften überall seine Verdienste hervorhebt; es entsprach dies dem allgemeinen Brauch, der bei dem literarischen Piratentum vielleicht sogar notwendig war". (A. BURCкHARDT, Geschichte der Medizinischen Fakultät, s. 99).

117 Památník Caspara Bauhina, UB Basel AN VI 16, fol. 98r: „Deum timere et diligere / se ipsum cognoscere et amare / proximo benefacere et / qua quisque ratione potest ac dedit servire." 
i samostatné gratulační sborníky a zčásti i zápisy v památnících. Pramenem par excellence je korespondence studentů zachovaná v Basilejské univerzitní knihovně.

Dosud neprozkoumaným tématem, které je v této studii pouze nastíněno, je role Basileje jako místa básnických laureací studentů z českých zemí, spojená s osobností J. J. Grassera. Další informace o literárním provozu v prostředí basilejské univerzity, o dedikačních praktikách a o nepublikované nebo nezachované literární tvorbě v budoucnu nepochybně přinese podrobnější výzkum korespondence studentů s profesory. Desideratem je zatím také obraz Basileje a tamních univerzitních profesorů $\mathrm{v}$ literárních dílech vzniklých $\mathrm{v}$ době pobytu studentů nebo po jejich návratu.

Mezi otázky, na něž se bude moci zaměřit detailněji teprve další výzkum, patř́i např́ílad vliv basilejských studií medicíny na vývoj lékařské teorie a praxe v českých zemích, stejně jako její propojení se zahraničními diskurzy. Podobně by se ovšem mohlo další bádání soustředit i na řadu dalších otázek (mecenát sledovaných osobností, detailnější rozkrytí jejich kontaktů s evropskou obcí učenců, jejich knihovny apod.). Cenné by pak bylo rovněž srovnání studií medicíny obyvatel z českých zemí v Basileji s jinými zahraničními univerzitami.

\section{Grantová podpora a poděkování}

Studie vznikla v rámci řešení grantu Basilejská univerzita a české země (1460-1630) (Grantová agentura ČR; reg, č.: GA21-00227S). Poděkování autorů za pomoc při rešerších a získávání pramenného materiálu patří paní Yvonne Häfner z Universitätsbibliothek Basel.

\section{MILITES APOLLINIS. MEDIZINSTUDENTEN AUS DEN BÖHMISCHEN LÄNDERN AN DER UNIVERSITÄT BASEL IM 16. UND FRÜHEN 17. JAHRHUNDERT}

\section{ZUSAMMENFASSUNG}

In der frühen Neuzeit war die Basler Universität häufiges Ziel von nichtkatholischen Studenten aus den böhmischen Ländern. Ab der zweiten Hälfte des 16. Jahrhunderts kamen außer zahlreichen Adelsgruppen auch Studenten stadtbürgerlicher Herkunft an die Universität, namentlich Interessenten für das Medizinstudium, das die Prager Universität damals nur in beschränktem Maße ohne die Möglichkeit der Erlangung eines akademischen Grades anbot. Diese Gruppe von Studenten, auf deren geografisches, soziales bzw. Bildungsprofil sich vorliegende Studie konzentriert, waren relativ vermögend (sie waren nicht, wie beispielsweise die adligen Präzeptoren, auf fremde Unterstützung angewiesen) und unabhängig. Typisch für sie ist auch die Zielstrebigkeit im Studium, das auf die Erlangung der medizinischen Doktorwürde abzielt. Die meisten von ihnen hatten schon vorher andernorts studiert, zum Beispiel in Wittenberg, Helmstedt, Altdorf oder Straßburg. Während ihres Studiums in Basel gingen viele von ihnen für eine Zeitlang beispielsweise nach Padua oder Montpellier, um am Ende nach Basel zurückzukehren und dort die Doktorprüfung abzulegen. Ein in Basel abgeschlossenes Medizinstudium war an sich schon eine ausgezeichnete Empfehlung, und die meisten Absolventen fanden eine gute Betätigung, sei es als Ärzte in böhmischen und mährischen Städten oder als Ärzte und Professoren in der Fremde (Schaffhausen, Basel, Tübingen), was insbesondere die nachweißenbergischen Exulanten betraf. Während ihres Studiums in Basel gaben die Studenten 
ihre Arbeiten im Druck heraus, namentlich ihre Thesen, die von einer mannigfaltigen Gruppe von Paratexten begleitet ist, welche heute als Informationsquelle für das Umfeld der Studenten, ihre Kontakte im Rahmen der Universitätsgemeinde, das Mäzenatentum u.ä. dienen. Insbesondere vom Beginn des 17. Jahrhunderts an haben sich auch Promotionsglückwünsche in Sammelbänden erhalten, mit deren Hilfe es möglich ist, die Topik der Gratulationsgedichte für die neuernannten Doktoren der Medizin zu charakterisieren. Basel war auch Schauplatz von Auszeichnungen: der lokale Palatin Johann Jakob Grasser bekränzte zwei tschechische Dichter (Simeon Partlicius und Daniel Stolcius) mit dem Dichterkranz, ein anderer Medizinabsolvent, nämlich Jan Škréta Šotnovský von Závořice, der sich schließlich in der Schweiz niederließ, ist Verfasser einer ganzen Reihe bislang unterbewerteter Gelegenheitsgedichte. Ein Zeugnis für das Studentenleben und den Literaturbetrieb in Basel ist auch die reichhaltige, in der Basler Universitätsbibliothek erhaltene Studentenkorrespondenz mit Basler Professoren, deren Informationswert in diesem Beitrag bei weitem nicht ausgeschöpft wurde.

(C) Deutsche Übersetzung Wolf B. Oerter

prof. PhDr. Martin Holý, Ph.D.

Historický ústav $A V \check{C} R$

holy@hiu.cas.cz

Mgr. Marta Vaculínová, Ph.D.

Kabinet pro klasická studia Filosofického ústavu $A V \check{C} R$

vaculinova@ics.cas.cz

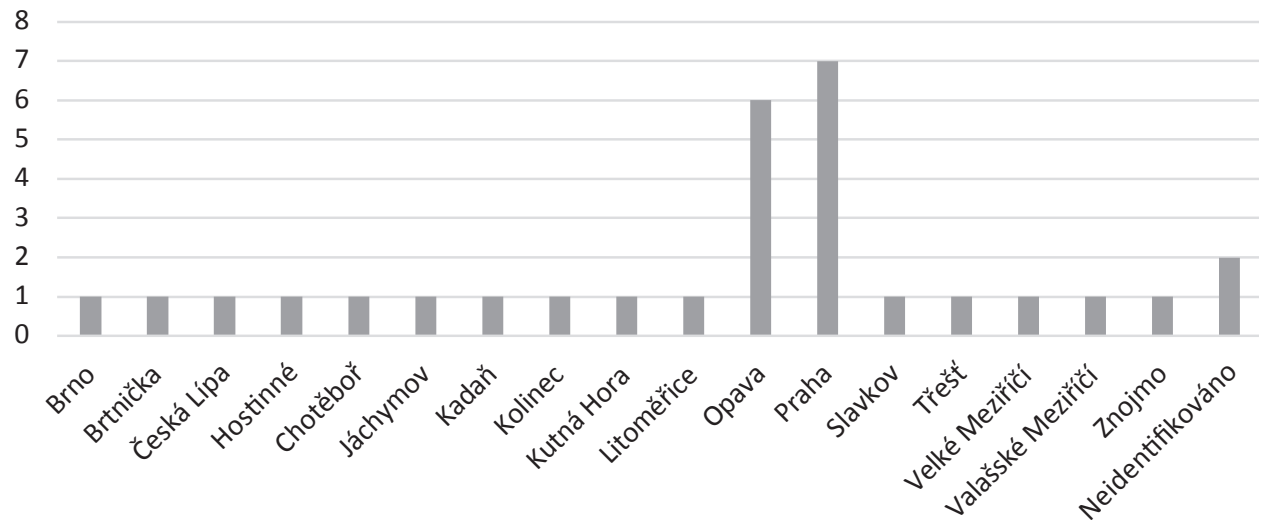

Geografický původ studentů medicíny z českých zemí na univerzitě v Basileji 


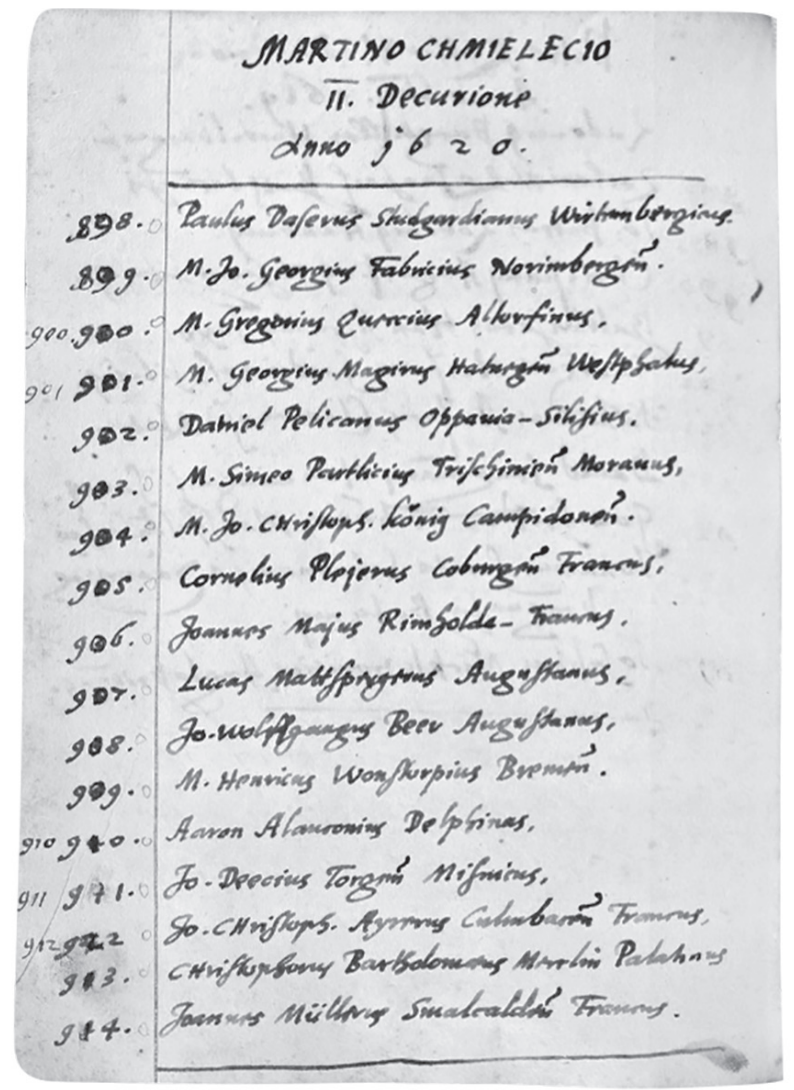

Obr. 1 Matrika lékařské fakulty k roku 1620 se zápisy jmen Daniela Pelikána a Simeona Partlicia (Universitätsbibliothek Basel, Matricula facultatis medicae, AN II 21, fol. 126v) 


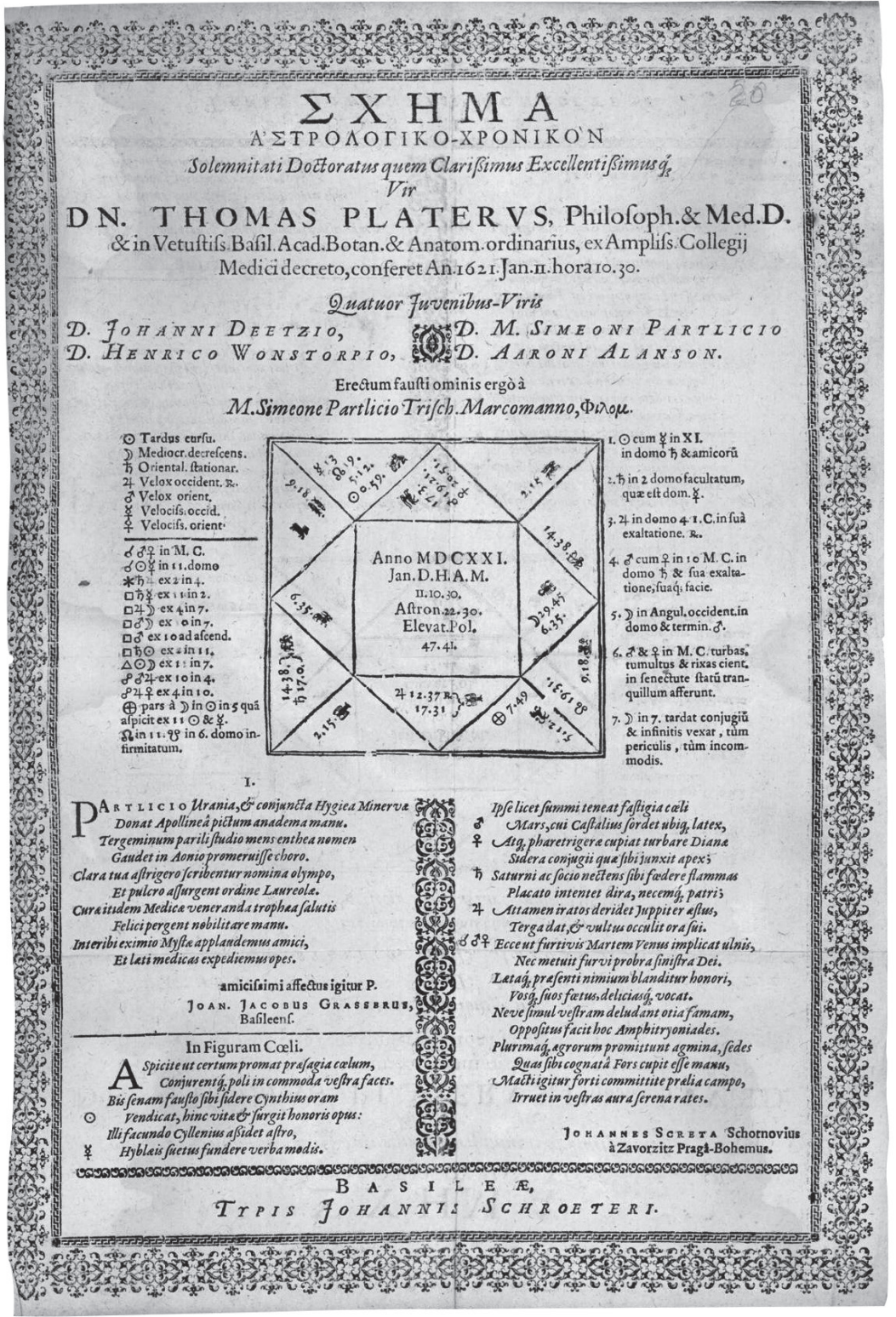

Obr. 2 Pozvánka na promoci Simeona Partlicia a dalších, Basilej: Johann Schroeter 1621, jednolist (ULB Sachsen-Anhalt, A 6436 (20)) 


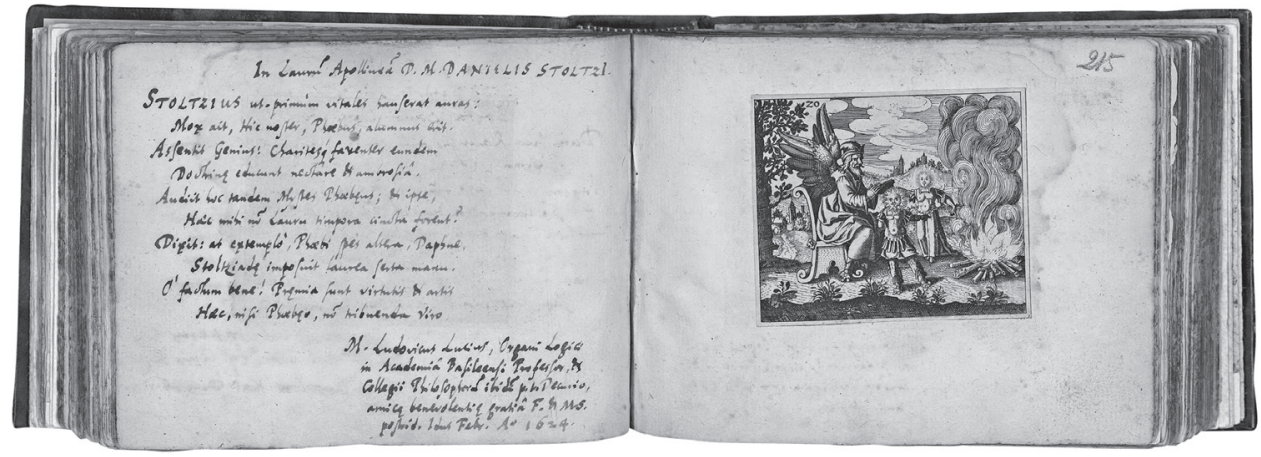

Obr. 3 Gratulační báseň profesora Ludwiga Lucia v památníku Daniela Stolcia (UB Uppsala, Y 132 d, fol. 214v-215r)

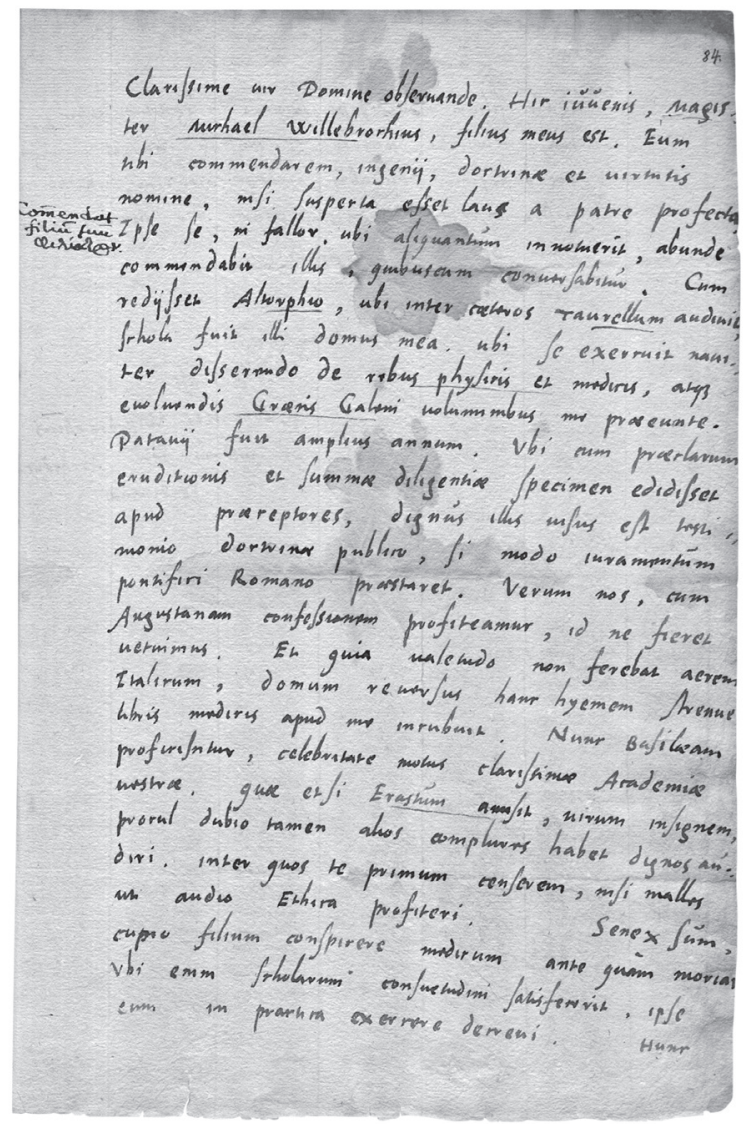

Obr. 4 Úvodní strana doporučujícího listu Jana Willebrocha Theodoru Zwingerovi staršímu, datovaného v Innsbrucku 14. 4. 1586 (Universitätsbibliothek Basel, Frey-Gryn Mscr I 11, fol. 84) 


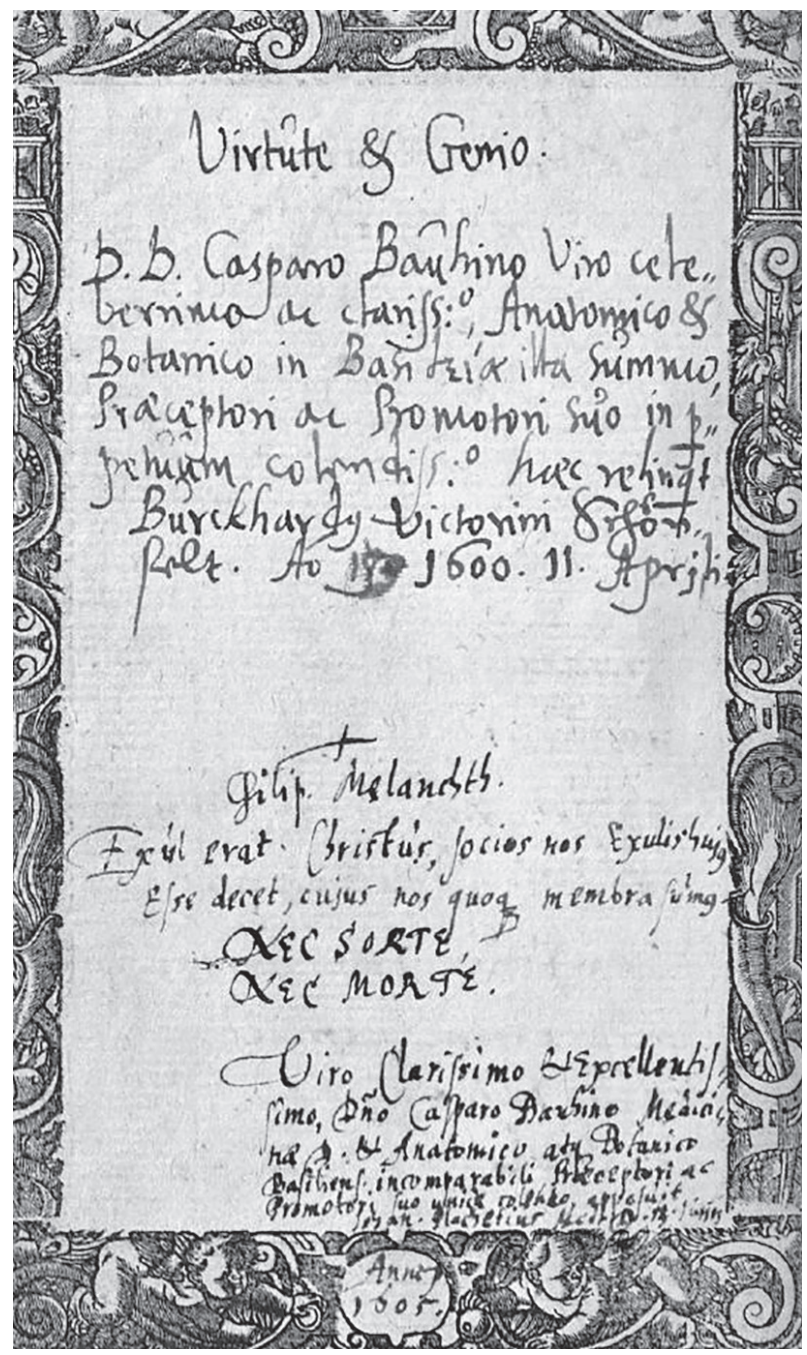

Obr. 5 Památník Caspara Bauhina, zápis Jana Plachetia (Universitätsbibliothek Basel, AN VI 16, fol.133r) 


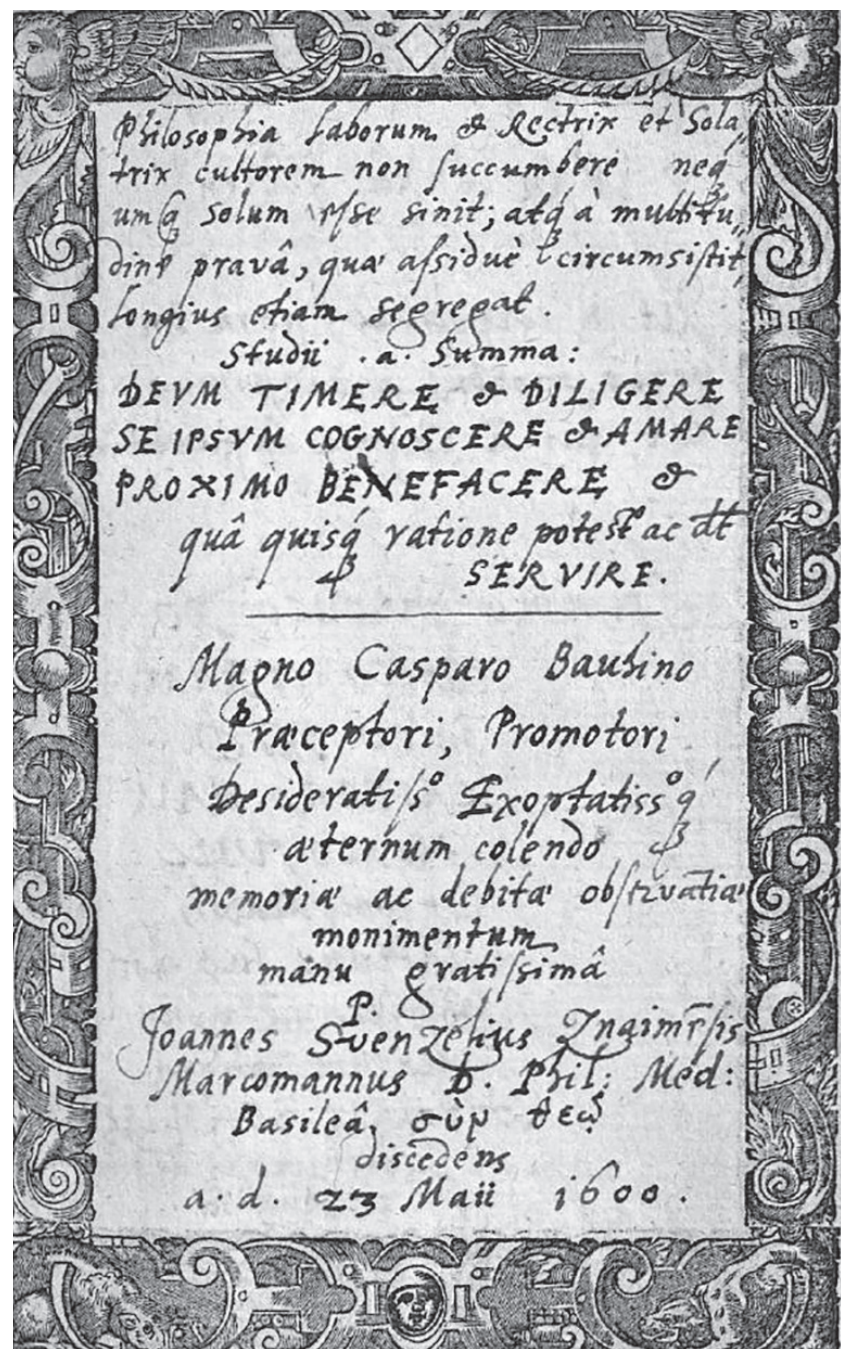

Obr. 6 Památník Caspara Bauhina, zápis Jana Svenzelia (Universitätsbibliothek Basel, AN VI 16, fol. 98r) 